\title{
32. HIMALAYAN UPLIFT, SEA LEVEL, AND THE RECORD OF BENGAL FAN SEDIMENTATION AT THE ODP LEG 116 SITES 1
}

\author{
James R. Cochran ${ }^{2}$
}

\begin{abstract}
Three closely spaced sites located $800 \mathrm{~km}$ south of Sri Lanka on the distal Bengal Fan were drilled during ODP Leg 116. Two of these sites, 717 and 718 , together penetrated over 1300 of the $2000 \mathrm{~m}$ of stratigraphic section present at that location and provide a complete record of sedimentation since the lower Miocene. The entire section consists of turbidites, primarily derived from the Ganges-Brahmaputra delta. The main controls on sedimentation appear to be the uplift and erosion history of the Himalayas, along with the position of sea level relative to the shelf edge. Although the base of the fan was not penetrated, a number of lines of evidence suggest that it was approached and that fan sedimentation began in the lower Miocene. This corresponds in time with the oldest known molasse sedimentation in India and Pakistan and probably represents the time of beginning of major uplift and erosion in the Himalayas. Sedimentation continued at a substantial rate from the lower Miocene to the upper Pliocene indicating continued erosion and thus presumably continuing uplift and significant relief in the Himalayas during that time.

The unconformity in seismic sections corresponding to the beginning of intraplate deformation can be dated as occurring between 7.5 and $8.0 \mathrm{Ma}$. It does not correspond to any change in the nature of the sediments. A change from the gray, silt-mud turbidites that had predominated throughout the Miocene to finer muddy, black organic-rich turbidites occurred in the uppermost Miocene. However, this occurred at 5.6-6.7 Ma in the Messinian, 1-2 m.y. after the beginning of the intraplate deformation. The Messinian change in the character of the sediments appears to result from a rise in mean sea level which occurred at that time. The beginning of intraplate deformation is probably due to a change in the plate boundary forces, perhaps resulting from the beginning of east-west extension in southern Tibet.

A return to the deposition of coarser, silty turbidites occurred in the upper Pleistocene at about 800 ka. These sediments accumulated at very high rates until the Holocene. The beginning of the deposition of this unit corresponds in time to the marked intensification of the Pliocene-Pleistocene glaciations. The greater sea level variations resulting from the more intense glacial cycles may have resulted in completely exposing the shelf during glacial maximum with the sediment load of the rivers delivered directly to the continental slope.
\end{abstract}

\section{INTRODUCTION}

The collision between India and Eurasia has not only resulted in the construction of the Himalaya mountains at the site of the collision, but also has had far-reaching consequences for the tectonics of much of Asia (Molnar and Tapponnier, 1975; Tapponnier et al., 1982, 1986) and for the Indian Ocean lithosphere formed in the wake of India (Norton and Sclater, 1978; Weissel et al., 1980; Wiens, 1985). One significant geologic consequence of the collision within the Indian Ocean has been the construction of the Indus and Bengal fans. In particular, the Bengal Fan is the world's largest submarine fan, covering an area of $3 \times 10^{6} \mathrm{~km}^{2}$ and extending $3000 \mathrm{~km}$ from the continental slope south of the Ganges-Brahmaputra delta to well south of the Equator near the Afanaziy-Nikitin seamount group (Fig. 1) (Curray and Moore, 1971; Emmel and Curray, 1984).

Since this enormous volume of sediment has been primarily derived from the Ganges-Brahmaputra River system (Curray and Moore, 1971), it contains a record of the erosion and thus the uplift of the Himalayas. However, prior to ODP Leg 116, the sediment composition, stratigraphy, and history of the Bengal Fan had not been extensively investigated. Fewer than 100 short piston cores have been recovered from the fan (Curray and Moore, 1971; Curray et al., 1982) and only one spot-cored DSDP drill site (Leg 22, Site 218 ) was located on it. Site 218 , located east of Sri Lanka

\footnotetext{
1 Cochran, J. R., Stow, D.A.V., et al., 1990. Proc. ODP, Sci. Results, 116: College Station, TX (Ocean Drilling Program).

2 Lamont-Doherty Geological Observatory, Columbia University, Palisades, NY 10964, U.S.A.
}

near $8^{\circ} \mathrm{N}, 86^{\circ} 17^{\prime} \mathrm{E}$ (Fig. 1), penetrated 772 mbsf (meters below seafloor) and reached middle Miocene sediments. Four main pulses of sandy turbidites were identified (Shipboard Scientific Party, 1974; Thompson, 1974), one in the middle Miocene, two in the late Miocene-Pliocene, and the most recent in the Pleistocene. However, the succession of sediments at Site 218 could not be directly related to Himalayan tectonics.

\section{Bengal Fan Stratigraphy}

Curray and Moore (1971) described the stratigraphy of the Bengal Fan based on $3.5 \mathrm{Khz}$ echosounder, seismic profiler, and wide angle reflection (sonobuoy) data. They divided the fan into three gross stratigraphic units separated by unconformities in the seismic records. The upper sequence consists of relatively undeformed sediments that unconformably lap onto a second sequence of deformed sediments. These two units were interpreted as younger and older fan sediments. They overlie another sedimentary unit interpreted as pre-fan sediments that are apparently distinguished from the other units by a lack of the acoustic layering and buried channels characteristic of the fan turbidite sequence. Moore et al. (1974) state that this lower unit and the unconformity separating it from the overlying sediments are best recorded on seismic records from on the flanks of the Ninetyeast Ridge. Curray et al. (1982) identified the lower unconformity with an interface which they recognized on seismic refraction lines in the Bay of Bengal, separating sediments with seismic velocities in the range of $2.5-3.5 \mathrm{~km} / \mathrm{s}$ from sediments with velocities greater than $4.0 \mathrm{~km} / \mathrm{s}$.

Moore et al. (1974) attempted to date the two unconformities identified by Curray and Moore (1971) by tracing them on 


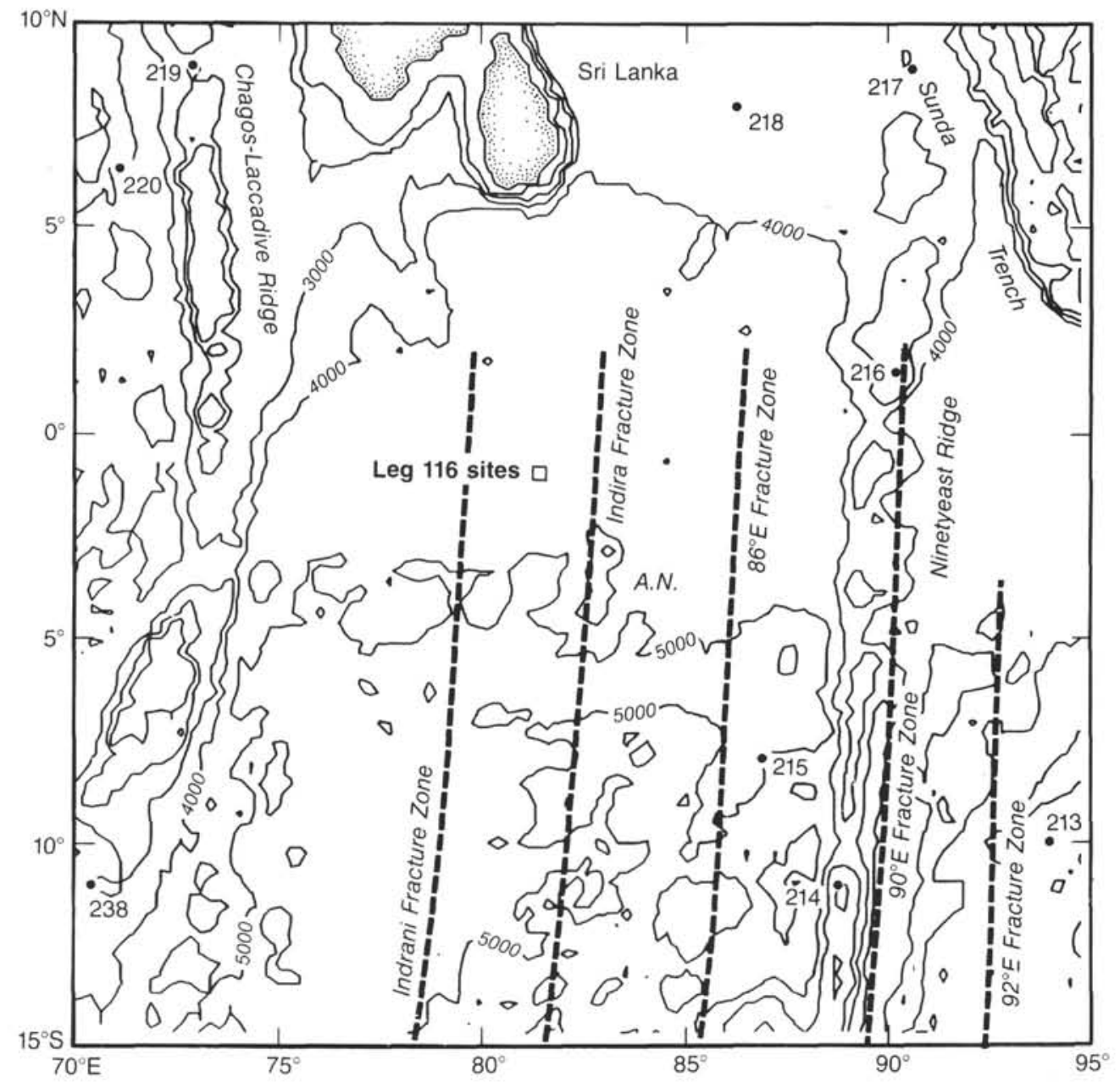

Figure 1. Location map showing position of the Leg 116 sites within the Central Indian Ocean. Small dots show location of prior DSDP sites. Afanaziy Nikitin seamounts are labeled A.N. Bathymetry is machine-contoured DBDB-5 bathymetry contoured at 1-km intervals.

seismic reflection records to DSDP sites. They traced the lower unconformity to Site 217 on the eastern flank of the Ninetyeast Ridge near $8^{\circ} 56^{\prime} \mathrm{N}$ and concluded that it coincides with a hiatus between the Paleocene and the middle Eocene. The upper unconformity was traced to Site 218 where it was assigned an upper Miocene age (Moore et al., 1974). The upper unconformity has been interpreted as marking the onset of the intraplate deformation observed over a wide portion of the central Indian Ocean (Moore et al., 1974, Weissel et al., 1980; Geller et al., 1983).

The Eocene date assigned by Moore et al. (1974) to the lower unconformity of Curray and Moore (1971) could be interpreted as implying that fan sedimentation, and thus uplift and erosion on land, began at that time. However, the erosion history of the Himalayas, as recorded by the fan sediments, has not been determined. ODP Leg 116 Sites 717 and 718 collectively penetrated $1300 \mathrm{~m}$ of the $2000 \mathrm{~m}$ of stratigraphic section present at $1^{\circ} \mathrm{S}$ on the distal Bengal Fan and obtained a continuous record of the sedimentary history of the distal fan from the lower Miocene to the present. The purpose of this paper is to examine that sedimentary record in order to determine what factors have influenced it and what information it contains on the geologic history of the region. Of particular interest is to what extent the sedimentary record reflects the erosion, and thus uplift, history of the Himalayan Mountains.

\section{The Central Indian Ocean and the Himalayas}

An intimate relationship exists between tectonic events in the Himalayan collision zone to the north of India and in the central Indian Ocean to the south, as both result from and record the northward motion of India and the closing of the Tethys beginning in the Late Cretaceous. Formation of the Indian Ocean began in the Jurassic with the breakup of Gondwanaland into eastern (India, Madagascar, Australia, Antarctica) and western (Africa, Arabia, South America) portions. Eastern Gondwanaland moved to the south relative to Africa (Bunce and Molnar, 1977; Scrutton, 1978) with India and Madagascar left behind in the middle Cretaceous by the formation of a spreading center between India and Australia/ Antarctica (Markl, 1974, 1978; Larson et al., 1979) combined with the cessation of spreading at the Somali Basin spreading center (Segoufin and Patriat, 1980; Cochran, 1988).

Rifting between Madagascar and India occurred in the upper Cretaceous with seafloor spreading beginning at about the time of magnetic anomaly 34 (Schlich and Fondeur, 1974; Schlich, 1982). India then moved rapidly northward, carrying with it the Tethyan oceanic crust to its north. This oceanic 
lithosphere was consumed in a subduction zone along the southern margin of Eurasia. The location of the volcanic arc associated with the subduction zone is now marked by the Trans-Himalayan granitic batholith, which extends for over $2500 \mathrm{~km}$ just to the north of the Indus-Tsangpo suture zone (Tapponnier et al., 1981; Brookfield and Reynolds, 1981; Honegger et al., 1982).

The northern continental margin of India appears to have encountered the subduction zone in the Eocene. Prior to this time, India was moving northward at an exceptionally fast rate. Half spreading rates recorded by magnetic anomalies in the central Indian Ocean during this time are greater than 8 $\mathrm{cm} / \mathrm{yr}$ (McKenzie and Sclater, 1971; Sclater and Fisher, 1974; Schlich, 1982). This is the highest spreading rate known for a plate bearing a significant amount of continental lithosphere, and the only place where present-day spreading rates approach this value is the "superfast" segment of the East Pacific Rise.

The spreading rates in the central Indian Ocean decreased sharply to half rates of $4-5 \mathrm{~cm} / \mathrm{yr}$ at the time of magnetic anomaly 22 (middle Eocene-about $50 \mathrm{Ma}$ ) (Sclater and Fisher, 1974). The initial studies (Sclater and Fisher, 1974; Sclater et al., 1976) showed a further decrease in spreading rate to a half rate of $2.5 \mathrm{~cm} / \mathrm{yr}$ between anomalies 17 and 20 (40-44 Ma), which was also accompanied by a change in the spreading direction on the Southeast Indian Ridge from nearly north-south to northeast-southwest. These observations have been widely interpreted as marking the collision between India and Asia (e.g., Molnar and Tapponnier, 1975; Johnson et al., 1976; Curray et al., 1982; Schlich, 1982; Molnar, 1986).

Later more-detailed analyses (Patriat and Achache, 1984; Molnar et al, 1988; Patriat and Seguofin, 1988; Royer and Sandwell, 1989) have confirmed this basic sequence of events, although there is disagreement concerning the exact chronology. Disagreements between the various reconstructions arise partially from the use of different magnetic time scales, partially from different techniques for the analysis, and also at least partially from inadequacies in the data set. However, all of the studies conclude that the development of the Indian Ocean began to be influenced by the India-Eurasia collision in the lower to middle Eocene (about 55-50 Ma) and that a seafloor spreading pattern not unlike the present was established in the eastern Indian Ocean by the end of the Eocene.

Evidence from the continent also indicates that the collision occurred in the Eocene. Radiometric dating of the plutonic rocks of the Trans-Himalayan Batholith show that the youngest intrusions occurred about $40 \mathrm{Ma}$ (Honegger et al., 1982; Reynolds et al., 1983; Scharer et al., 1984; Petterson and Windley, 1985) and therefore that subduction of oceanic crust had ceased by that time. Mercier et al. (1987) state that "the first compressional deformations, which clearly demonstrate that an India-Asia collision occurred, affect formations of Lower Eocene age and probably took place in the Middle Eocene (45-40 m.y. B.P.)"' (Mercier et al., 1987, p. 299). Searle et al. (1987) summarized stratigraphic information indicating that the youngest shelf sediments on the Tethyan margin of the Indian Plate are fossiliferous lower Eocene limestones, while in the Indus-Tsangpo suture zone, marine flysch deposition ended in the upper Cretaceous and coarse, clastic, mostly conglomeratic, molasse-like deposition began in the Eocene. In addition, Sahni and Kumar (1974) state that terrestrial mammals have not been reported from lower Eocene or older formations in India, but that their abundance and diversity in the middle Eocene suggests the presence of a land connection with Mongolia at that time.

Although the age of the collision between India and Asia is fairly well constrained, the subsequent sequence of tectonic events and in particular the history of uplift in the Himalayas and Tibet has remained controversial. Paleomagnetic and plate reconstruction studies indicate that approximately 3000 $\mathrm{km}$ (with large error bounds) of convergence have occurred between Eurasia and India since the lower Eocene (Molnar and Tapponnier, 1975; Klootwijk, 1981; Patriat and Achache, 1984; Klootwijk et al., 1985). Approximately $2000 \mathrm{~km}$ or more of this convergence appears to have been accommodated in Tibet and farther north in Asia (Molnar et al., 1981; Achache et al., 1984; Klootwijk et al., 1985). The shortening within Eurasia appears to have been largely accomplished by "escape tectonics" and the eastward expulsion of southeast Asia, south China, and northern Tibet (Molnar and Tapponnier, 1975; Tapponnier and Molnar, 1977; Tapponnier et al., 1986; Armijo et al., 1989). The remaining convergence between India and Eurasia occurred within and south of the IndusTsangpo suture, largely by thrust faulting and subduction of Indian continental crust and lithosphere. The timing of the motion on the Himalayan thrusts, which is responsible for the relief of the Himalayas has remained controversial.

Powell and Conaghan (1973) pointed out that the initial collision did not cause uplift as nummulitic limestones were deposited in the middle Eocene throughout the Himalayan region south of the suture and these sediments do not contain a significant clastic component. Powell and Conaghan (1973) argued that underthrusting began in the lower Miocene and that maximum uplift occurred in the Pliocene and lower Pleistocene. Powell (1986) claimed that, during the Miocene, major motion occurred on the Main Central Thrust, the northern of the two major thrusts south of the suture zone, with movement shifting south to the Main Boundary Thrust during the Pliocene. Le Fort (1986) interpreted $\mathrm{K} / \mathrm{Ar}$ ages obtained from minerals in the metamorphic zone associated with the Main Central Thrust as indicating that motion occurred on the fault at between 15 and $20 \mathrm{Ma}$.

Gansser (1964, 1966, 1981a, 1981b) also considered major thrusting to have begun in the Miocene, but argued that there were two distinct orogenic phases in the Miocene and in the Pleistocene. He considered the Miocene phase to have been the most important. Gansser equated the two orogenic phases with motion on the Main Central Thrust and on the Main Boundary Thrust respectively. He also suggested that, between these two orogenic phases, relief may have been much lower than presently observed.

Besse et al. (1984) used paleomagnetic techniques to estimate that approximately $400 \mathrm{~km}$ of shortening has occurred within the Indian continental crust south of the Indus-Tsangpo suture since $50 \mathrm{Ma}$. Besse et al. (1984) state that much of this shortening occurred by thrusting between 45 and $35 \mathrm{Ma}$, but it is not clear from their discussion to what extent these dates result from their analysis and to what extent they are an assumption. A number of discussions of shortening mechanisms, such as that of Mattauer (1986) assume that southward thrusting, and thus presumably uplift, began in the upper Eocene.

\section{DRILLING ON THE BENGAL FAN}

During ODP Leg 116, three sites were drilled on the distal Bengal Fan approximately $800 \mathrm{~km}$ south of Sri Lanka near $1^{\circ} \mathrm{S}, 81^{\circ} 24^{\prime} \mathrm{E}$. A seismic reflection profile across the drill sites is shown in Figure 2. The sites are located on two adjacent fault blocks bounded by near-vertical faults. Rotated fault blocks such as those apparent in Figure 2 form the "short wavelength" expression of the intraplate deformation affecting the central Indian Ocean (Weissel et al., 1980, Geller et al., 1983). 
N

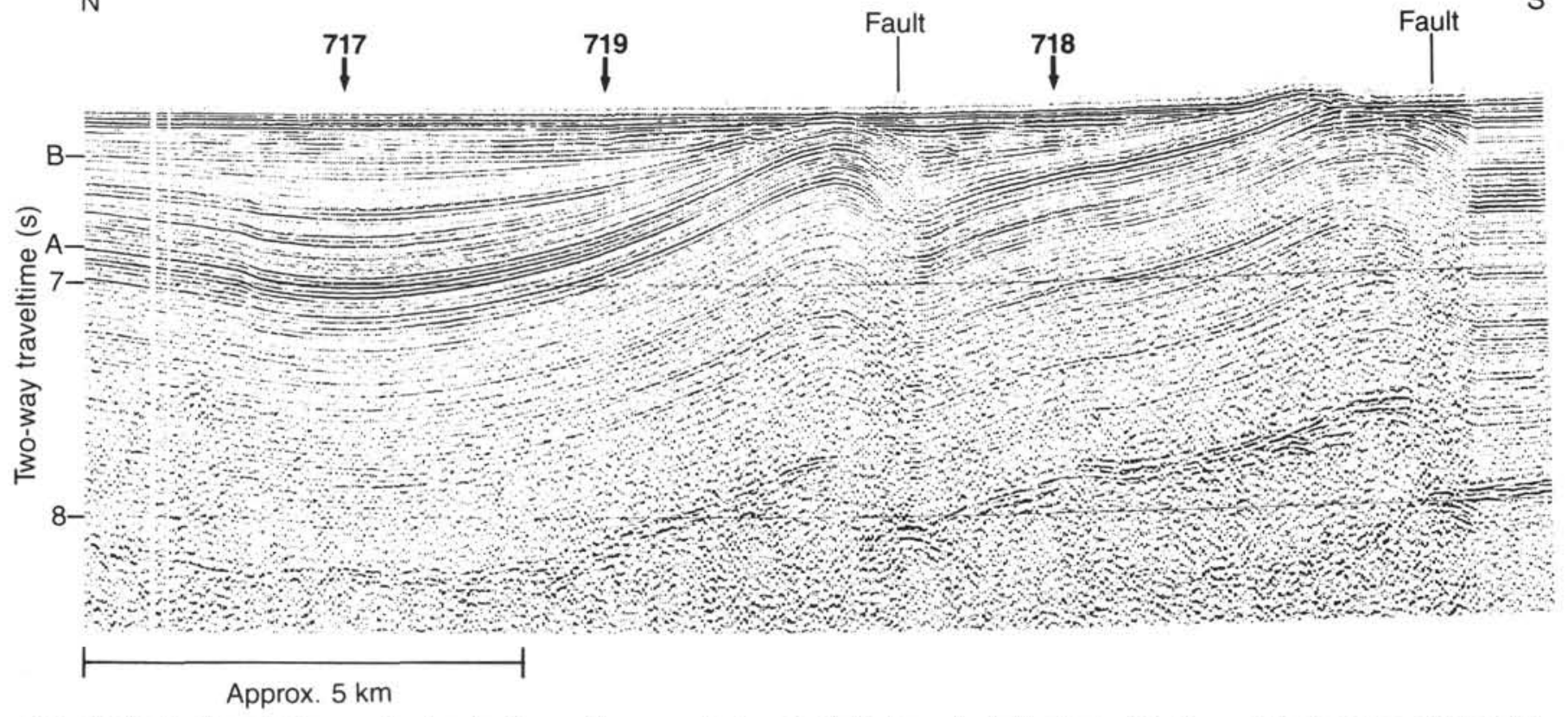

Figure 2. Single-channel air-gun seismic reflection profile across the Leg 116 drill sites collected by Robert D. Conrad. The locations of Sites 717 , 718 , and 719 are noted as are the faults bounding the tilted fault blocks. "A" and "B" are prominent unconformities discussed in the text.

The sediments in the region of the Leg 116 sites vary in thickness from about 1.30 to $1.95 \mathrm{~s}$ (two-way traveltime). They are divided into pre-deformation and syn-deformation seismic units by an unconformity labeled " $A$ " in Figure 2. The pre-deformation sediments below unconformity "A"' are $1.15-1.35 \mathrm{~s}$ thick throughout the site survey area and have a nearly constant thickness on each fault block (Shipboard Scientific Party, 1989a). Seismic reflectors within this sequence are parallel to each other and to the basement.

The syn-deformation sediments above unconformity "A" have a maximum thickness of about $0.7 \mathrm{~s}$ and thin, with individual reflectors pinching out, toward the crests of the fault blocks. A second prominent unconformity labeled "B" occurs within the syn-deformation sediments at a depth of about $200 \mathrm{~ms}$ below the sea bottom. The sediments above unconformity " $\mathrm{B}$ " are essentially flat lying and lap onto the uplifted sediments on the crests of the fault blocks. Reflectors within the underlying sediments appear in places to be truncated by the unconformity.

Site 717 was drilled through the thickest sequence of syn-deformation sediments, which is located near the lower (northern) edge of the northern of the two fault blocks shown in Figure 2. Unconformity "A" appears to become conformable in the vicinity of Site 717, suggesting that a fairly complete section of syn-deformation sediments was obtained. Site 719 is located part-way up the fault block where unconformity " $A$ " is well developed and the syn-deformation sequence has thinned from $0.70 \mathrm{~s}$ at Site 717 to $0.52 \mathrm{~s}$ (Fig. 2). The purpose of Site 719 was to determine the history and nature of motion on the fault through comparison of its sedimentary section with that obtained at Site 717 .

Site 718 is located on the adjacent fault block. It was situated on a local heat flow high to investigate the possibility of hydrothermal circulation through the sediments. However, because the southern fault block sits higher and has a very condensed syn-deformation section, the site also provided an opportunity to drill into the pre-deformation sequence and obtain a record of sedimentation extending further back in time. This site was drilled to a total depth of $961.6 \mathrm{~m}$, reaching lower Miocene sediments, before deteriorating hole conditions forced it to be abandoned.

Summary lithostratigraphic columns for the three sites are shown in Figure 3. The section has been divided into five lithologic units (Cochran, Stow, et al., 1989). Unit l, which is only $2-5.5 \mathrm{~m}$ thick, consists of calcareous clay and some thin mud turbidites and appears to represent the Holocene and perhaps also the uppermost Pleistocene. This is underlain by Unit II, which is made up of a sequence of silty turbidites, 98-147.5 m thick, which accumulated very rapidly during the upper Pleistocene. Recovery was quite poor in this unit and it is believed that the unrecovered intervals represent sections with a higher silt-to-mud ratio, or with coarser and cleaner silt (Shipboard Scientific Party, 1989b).

Units III and IV are made up primarily of finer grained mud turbidites of uppermost Miocene through upper Pliocene age. These two units are differentiated from each other by the presence of distinctive green and white biogenic turbidites in Unit III. Unit IV is also characterized by two pulses of coarser silty turbidites at Site 717. Sediment accumulation rates at Site 717 , where these units are best developed averaged about 70 $\mathrm{m} / \mathrm{m}$.y. through the Pliocene. The lower Pleistocene and uppermost Pliocene appears to be either very condensed or missing (Fig. 4).

The final lithostratigraphic unit is an extremely thick, extremely monotonous sequence of grey silty mud turbidites which accumulated at an average rate of about $75 \mathrm{~m} / \mathrm{m}$.y. Below a depth of 605 mbsf, intervals of interbedded mud turbidites, biogenic turbidites and pelagic clays up to $20 \mathrm{~m}$ thick were encountered. This unit was still being penetrated at the base of Hole 718E.

The oldest biostratigraphic horizon identified at Site 718 by Gartner (this volume) is the highest occurrence of Helicosphaera ampliaperta (16.2 Ma) at a depth of $778.8 \mathrm{mbsf}$. However, Spenolithus heteromorphus was observed in Sample 116-718E-2R, $64 \mathrm{~cm}$ ( $943.2 \mathrm{mbsf})$. The age of this sample, located only $18.3 \mathrm{~m}$ above the bottom of the hole, must be younger than the lowest occurrence of this species, which occurs at 17.1 Ma. Therefore, the age of the oldest sediment 


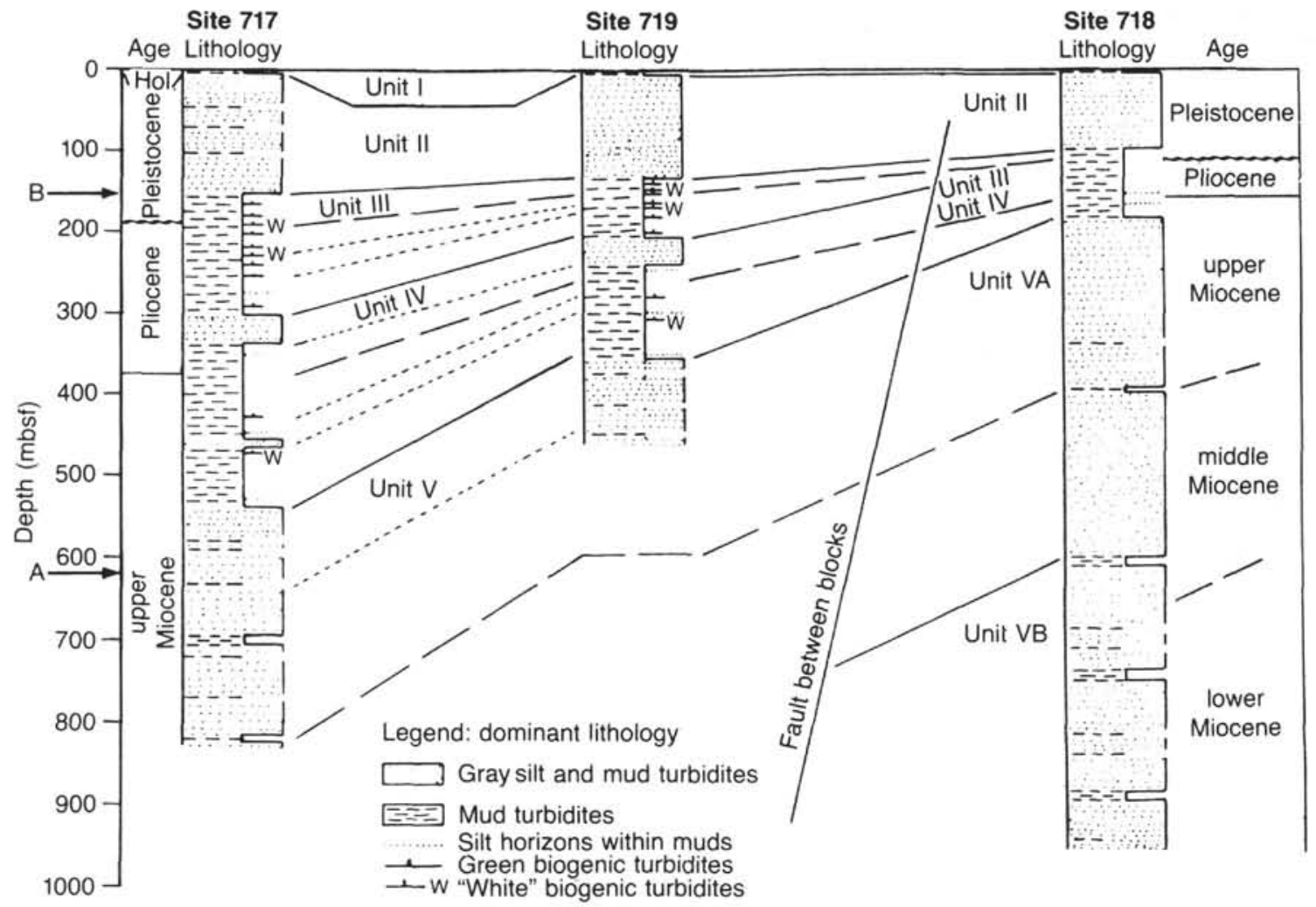

Figure 3. Lithostratigraphic columns for Leg 116 drill sites showing correlations between the sites. The location of unconformities " $\mathrm{A}$ " and " $\mathrm{B}$ " within the sections, as determined from well-log data, is also shown. Location of the drill sites relative to each other and to the tilted blocks making up the structural fabric of the area can be seen on Figure 2.

penetrated at Site 718 can not be more than about $17-17.5 \mathrm{Ma}$. This datum is marked by an open symbol on Figure 4.

The stratigraphic column at the Leg 116 sites thus consists almost exclusively of turbidites. These have been divided into four main facies (Stow, Cochran, et al., 1989), of which two constitute the vast majority of the sediments. The most common is gray micaceous silt and silty mud turbidites up to $2.5 \mathrm{~m}$ thick which make up the bulk of stratigraphic Units II and $\mathrm{V}$. The maximum grain size at the base of the thicker turbidites is coarse sand. The second facies is very dark grey to black mud or silty mud turbidites from a few $\mathrm{cm}$ to $1.5 \mathrm{~m}$ thick, which are the main constituent of stratigraphic Units III and IV. The sediments of these two facies are clearly of continental origin as demonstrated, for example, by the common occurrence of terrigenous woody plant debris.

Stow, Cochran, et al. (1989) argued that the gray silty turbidites originate at the Ganges delta based on their abundance and on their lack of microfossils, coupled with the presence of terrigenous plant debris. They pointed out that the turbidity currents must have been extremely large to deposit $2.5 \mathrm{~m}$ thick turbidites including coarse sand-sized quartz grains $2500 \mathrm{~km}$ from the source. Stow, Cochran, et al. (1989) also concluded that the very dark gray or black muddy turbidites, which are rich in organic carbon, are probably derived from similar large-scale slumps on a more anoxic part of the upper slope. They stated that they cannot determine whether these turbidites come from the northern end of the Bay of Bengal adjacent to the delta or from some other part of the continental margin.

There were also two types of biogenic turbidites; olivegreen nannofossil/clay-rich turbidites and white or buff colored carbonate silt-rich turbidites. Stow, Cochran, et al. (1989) concluded that the pale colored turbidites, which have no terrigenous content were derived from a local seamount source, such as the Afanaziy-Nikitin seamounts, while quartz silt and abundant resedimented benthic shelf/slope forams and diatoms indicate a continental source for the greenish turbidites, possibly the Indian or Sri Lankan shelf. Although distinctive, the biogenic turbidites are volumetrically insignificant and are useful primarily as marker beds which facilitate correlation between the sections obtained at Sites 717 and 719 (Fig. 3).

A number of provenance studies of the ODP Leg 116 sediments based on mineralogy and isotope geochemistry have been undertaken. Bouquillon et al. (this volume) investigated the isotope geochemistry of the coarse grain fraction. They found that the mineralogy of the coarse fraction, which includes amphibole, tourmaline, and garnet, is characteristic of metamorphic gneisses and of granites. They also found that $\mathrm{H}, \mathrm{O}, \mathrm{Sr}$, and $\mathrm{Nd}$ isotope ratios are very similar to those of Himalayan formations, particularly those of the crystalline High Himalayas. Yokoyama et al. (this volume) studied the modal proportions and chemistry of the heavy minerals through the section. They concluded that for the main part the mineral assemblages are consistent with derivation from the metamorphic rocks of the Himalayas. The exceptions are some samples from stratigraphic Units III and IV which have affinities with either the basaltic rocks of the Deccan Traps or with metamorphic rocks found in southern India or Sri Lanka.

Brass and Raman (this volume) and Bouquillon et al. (this volume) examined the clay mineralogy of the sediments. The clay mineralogy studies determined that the clay sized fraction of the gray silty turbidites characteristic of stratigraphic Units II and V is predominantly illite and chlorite, while that of the dark muddy turbidites characteristic of stratigraphic Units III and IV contains large quantities of smectite and kaolinite. 


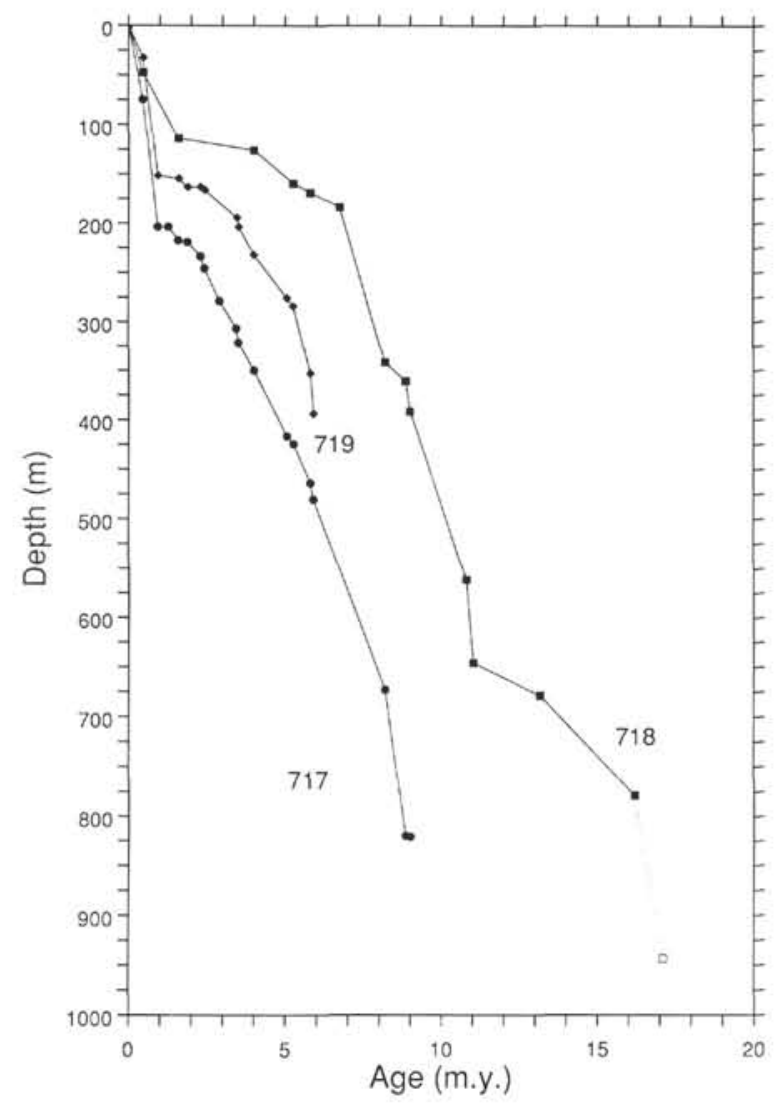

Figure 4. Plots of sediment age against depth for ODP Sites 717, 718, and 719. Data are from Gartner (this volume).

Bouquillon et al. (this volume) note that illite and chlorite are abundant in all stages between the Himalayas and the Leg 116 sites and conclude that they represent a characteristic signature of sediments derived from the Himalayas. Chlorite is a common product of the erosion of low grade metamorphic rocks and illite can be obtained from the weathering of siliceous igneous and high-grade metamorphic rocks. Bouquillon et al. (this volume) also point out that smectite and kaolinite are not common in sediments known to be derived from the Himalayas. Brass and Raman (this volume) consider the smectite to be the product of the weathering of basic igneous rocks, in particular the Deccan Traps. Bouquillon et al. (this volume) argue that the smectite could obtained by alteration of soils of the Indo-Gangetic plain originally of Himalayan origin. However, they state that the abundance of kaolinite argues against a Gangetic origin.

Both studies conclude that the source of the clay sized sediments at the ODP Leg 116 sites was almost entirely the Himalayas during the deposition of stratigraphic Unit V (lower Miocene to uppermost Miocene), that sediments from the Indian subcontinent were prominent during the deposition of stratigraphic Units III and IV (uppermost Miocene to middle Pleistocene) although there was still a significant contribution from the Himalayas, and that the rapidly deposited sediments of stratigraphic Unit II (middle Pleistocene to Holocene) were derived almost entirely from the Himalayas.

Thus, the distal fan section penetrated at the Leg 116 sites consists almost entirely of terrigenous sediments, in large measure delivered from the Himalayas by the Ganges and Brahmaputra Rivers. The sediments and their variation through time therefore record the erosion history and through it the uplift history of this region. However, there are also other major factors which influence the pattern of sedimentation on the distal fan. The most important of these appear to be variations in sea level and normal fan growth processes such as channel and lobe switching. The effects of these processes must also be evaluated to separate out the Himalayan erosion history.

\section{GEOLOGIC EVENTS RECORDED IN THE SEDIMENTARY RECORD}

The "Eocene Unconformity"

Curray and Moore (1971), on the basis of early seismic reflection studies, divided the Bengal Fan sedimentary section into three units separated by unconformities. They interpreted these units as younger and older fan sediments and pre-fan sediments. The upper unconformity of Curray and Moore (1971) separates deformed fan sediments from overlying undeformed sediments that lap onto the deformed section. It thus can be identified with unconformity " A"' at the Leg 116 sites (Fig. 2). Moore et al. (1974) traced seismic reflectors from a location where this unconformity was well developed to DSDP Site 218 and concluded that the unconformity is upper Miocene in age. This is in agreement with the results of Leg 116 drilling (Cochran, Stow, et al. 1989).

The nature of the lower unconformity was not discussed by Curray and Moore (1971). Moore et al. (1974) state that it is not clearly recorded on seismic records in the vicinity of Site 218 on the fan and that it is best recorded on seismic reflection records on the flanks of and over the Ninetyeast Ridge. Drilling at Site 217 on the Ninetyeast Ridge showed that a reflector identified by Moore et al. (1974) as the lower unconformity corresponds to an apparent hiatus in sedimentation between Paleocene and middle Eocene. Thus, where it is well defined, the lower unconformity consists of a hiatus or condensed section in the pelagic sedimentary sequence on the Ninetyeast Ridge, above the level of the fan or pre-fan sediments found off the ridge. This hiatus spans the time of collision between India and Eurasia and may be due to changes in the oceanic circulation resulting from the final closing of the Tethys to the north of India.

The relationship of this event in the pelagic section on the Ninetyeast Ridge to sedimentation off the Ninetyeast Ridge under the present fan, a region certainly below the lysocline and which probably had a significant clastic input from the continental margin of eastern India, is unclear. Curray and Munasinghe (1989) suggest that continental rise sedimentation was terminated at this time, but they do not explain why this should occur. The crucial question is whether the reflector associated with the unconformity can be traced off of the Ninetyeast Ridge and whether the layered Bengal Fan sequence can be shown to lap directly onto it.

The Glomar Challenger seismic records across Site 217 at $9^{\circ} \mathrm{N}$ show that the reflector identified with the Eocene unconformity does not extend off of the Ninetyeast Ridge to the east. To the west, the reflector does extend some distance under the fan turbidite sequence. However, at the expanded scale of the 3 -s sweep seismic records, there appears to be a transparent region between the reflector and the layered reflections of the turbidite sequence. The transparent region, which presumably represents non-turbidite (pelagic) sedimentation, is thin $(-0.05 \mathrm{~s})$ in the west and broadens toward the east on the flank of the Ninetyeast Ridge. This relationship seems to imply that the deposition of turbidites started after, although perhaps not long after, the event marked by the reflector on the Ninetyeast Ridge. Moore et al. (1974) also show a seismic record, which is of much better quality than the Glomar Challenger profile, across the west flank of the 
Ninetyeast Ridge approximately $275 \mathrm{~km}$ further south at $6^{\circ} 31^{\prime} \mathrm{N}$. A reflector on this profile, at the same position in the seismic section as the one identified with the Eocene hiatus at Site 217 , can be traced off of the Ninetyeast Ridge under the layered turbidite sequence. Here again, there appears to be a zone of transparent sediments $(\sim 0.1 \mathrm{~s}$ thick) between the turbidites and the reflector, which is within the pelagic section.

Their figures imply that Curray and Moore (1971) defined the base of the fan section, identified either by the base of distinct layering in the sediments or by the lack of buried fan channels, as the lower unconformity away from the Ninetyeast Ridge. This interface does divide the sediments into a fan sequence and a pre-fan continental rise sequence as stated by Curray and Moore $(1971,1974)$ and Moore et al. (1974). However, this boundary is almost certainly time transgressive and need not coincide in time with the hiatus in pelagic sedimentation observed on the Ninetyeast Ridge.

\section{Beginning of Fan Sedimentation at $1^{\circ} \mathrm{S}$}

Site 718 was situated on a fault block with a very attenuated syn-deformational sequence (Figs. 2, 3), allowing the older portion of the fan to be penetrated. Holes 718B, $718 \mathrm{C}$, and $718 \mathrm{E}$ together cored a section from the seafloor to 961.6 mbsf which bottomed in gray micaceous silty turbidites typical of those found throughout the entire Miocene sequence (Fig. 3). The biostratigraphy indicates an age of about 17-17.5 $\mathrm{Ma}$ (nannofossil zone $\mathrm{CN} 3$, foraminifer zone N8) for the base of Hole $718 \mathrm{C}$ at 935 mbsf.

Although Holes $718 \mathrm{C}$ and $718 \mathrm{E}$ did not penetrate the base of the Bengal Fan, they may have approached it. Lithostratigraphic Unit V is divided into Subunits VA and VB on the basis of the presence, in sediments older than middle Miocene, of mud-rich intervals 1 - to 20 -m thick comprised of thin bedded grayish-green silt-mud turbidites grading up into red- dish-brown clay and of thin white biogenic turbidites. This unit is also characterized by horizons of pelagic red and green clays, which become more common toward the bottom of the hole. The presence of the mud-rich intervals and the increasing presence of pelagic horizons suggests that the hole may be sampling the early stages of fan sedimentation when the distribution of terrigenous turbidites from the Ganges-Brahmaputra system was not as efficiently organized as later, thus allowing significant contributions from other sedimentary sources.

The same conclusion is suggested by plots of the maximum quartz grain size and carbonate content vs. depth (Fig. 5). The maximum grain size, which averages about $400 \mathrm{~mm}$ throughout the upper part of Unit V, decreases to generally less than $300 \mathrm{~mm}$ below about $700 \mathrm{~m}$ depth. The carbonate content of cores shows maximum values consistently in the range of $10 \%-15 \%$ throughout Unit V until a depth of about 800 mbsf. Below that depth, the carbonate content increases to $15 \%$ $25 \%$. Both of these observations again suggest that the fan was less well established during the deposition of the lower few hundred $\mathrm{m}$ of Site 718 sediments.

If an age of 17-17.5 Ma is assumed for the bottom of Hole $718 \mathrm{E}$, then the average sedimentation rate during the middle and lower Miocene is about $62 \mathrm{~m} / \mathrm{m}$.y., which is less than the rates of $93 \mathrm{~m} / \mathrm{m} . \mathrm{y}$. and $109 \mathrm{~m} / \mathrm{m} . \mathrm{y}$. obtained for the upper Miocene obtained from Sites 718 and 717 , respectively. The measured sedimentation accumulation rate in the lower part of Hole 718 is quite variable, and actually increases sharply to $182 \mathrm{~m} / \mathrm{m} . \mathrm{y}$. in the lower $150 \mathrm{~m}$ of Hole $718 \mathrm{C}$. However, this increase and the apparent period of slower sedimentation above it from about 16 to $11 \mathrm{Ma}$ are both most likely artifacts resulting from the sparse fossil assemblage and the resulting uncertainty in the exact location of biostratigraphic datums encountered at all of the Leg 116 sites (Gartner, this volume). Thus, although the lower and middle Miocene accumulation
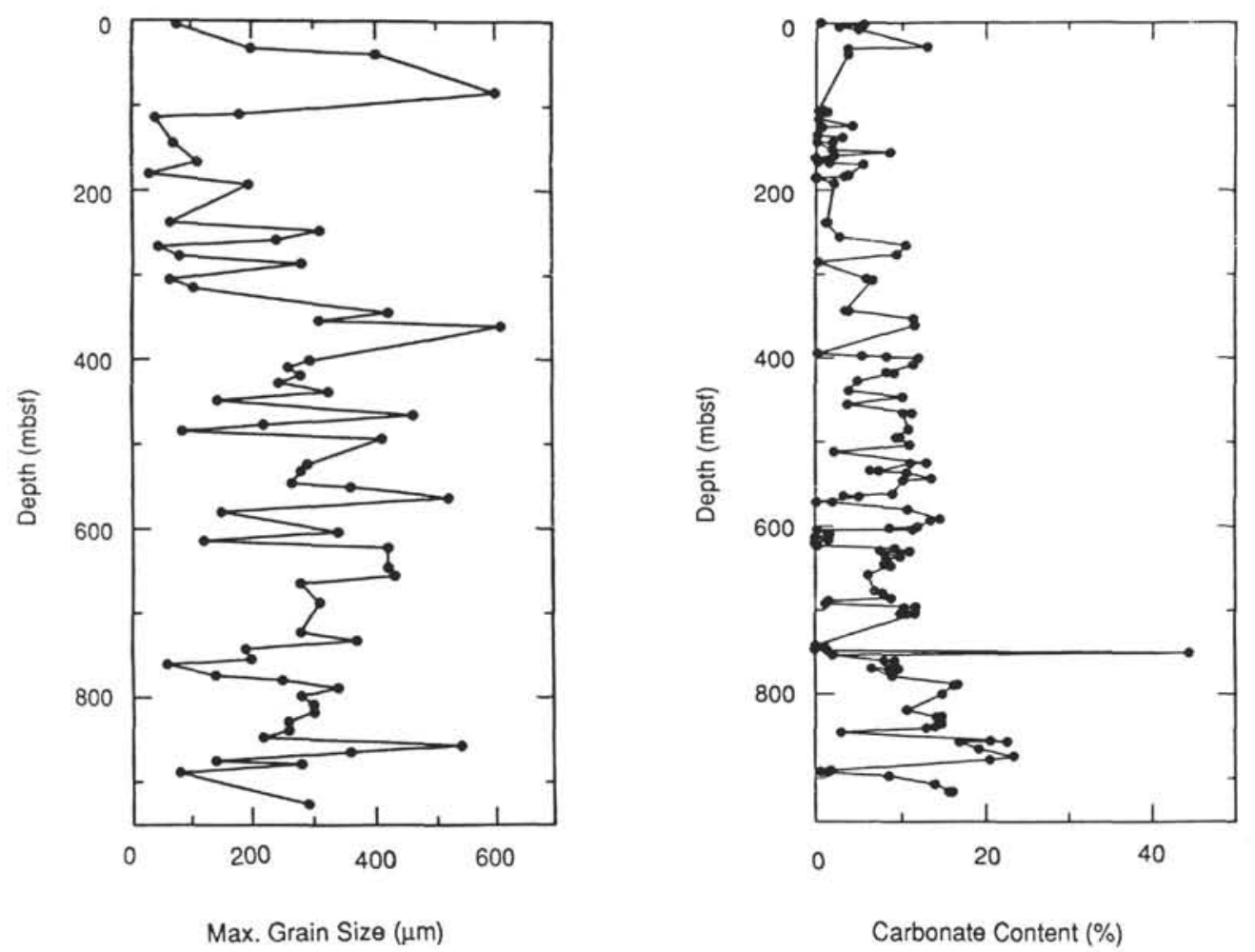

Figure 5. Plots of maximum grain size and calcium carbonate content against depth for ODP Site 718. 
rates are somewhat lower than those of the upper Miocene, it appears that, within the limitations of the biostratigraphic data, the sediment accumulation rate at the bottom of Holes $718 \mathrm{C}$ and $718 \mathrm{E}$ was at least as great as the rates which prevailed throughout the middle Miocene.

Seismic velocity measurements from the sonic logs show that the bottom of Hole $718 \mathrm{E}$ corresponds to about $0.99 \mathrm{~s}$ on seismic reflection records (Fig. 6). The seismic velocity in the lower several hundred meters of Hole $718 \mathrm{E}$ is in the range of $2.35-2.5 \mathrm{~km} / \mathrm{s}$. (Shipboard Scientific Party, 1989c) and, baring a major lithologic change such as the presence of significant chert, is not likely to increase very much more with depth. Wide angle seismic reflection data presented by Bull and Scrutton (this volume) give an interval velocity of $2.5-2.55$ $\mathrm{km} / \mathrm{s}$ for a layer corresponding to stratigraphic Unit $\mathrm{V}$. The total depth to basement at the location of Site 718 on seismic records is $1.55 \mathrm{~s}$. Thus, assuming a velocity of $2.5 \mathrm{~km} / \mathrm{s}, 700 \mathrm{~m}$ of sediment lies below the base of the hole, for a total sediment thickness of about $1650 \mathrm{~m}$. If the average middle and lower Miocene sedimentation rate of about $62 \mathrm{~m} / \mathrm{m} . \mathrm{y}$. also prevailed during the deposition of these older sediments, then the sediments lying directly on basement would have been deposited in the upper Oligocene. Because the age of the basement is $78 \mathrm{Ma}$ (Shipboard Scientific Party, 1989a), the sediment accumulation rate in the lower part of the section must be much less than those observed at Site 718 .

Bull and Scrutton (this volume) report a seismic $p$-wave velocity increase from 2.5 to $3.3 \mathrm{~km} / \mathrm{s}$ at a depth of $1250 \mathrm{~m}$ in their sonobuoy SB4, which they suggest might mark the base of the turbidite sequence. Allowing for the difference in the thickness of the syn-deformation sediments at Site 718 and at the midpoint of SB4, this velocity interface corresponds to a depth of about $1100 \mathrm{~m}$ at Site 718 . Assuming the lower and middle Miocene accumulation rate of $62 \mathrm{~m} / \mathrm{m} . \mathrm{y}$., a minimum age of $20 \mathrm{Ma}$ can be calculated for this depth. However, this velocity step was only observed on one of six sonobuoys, although Bull and Scrutton (this volume) state that they consider it to their highest quality line. There is therefore some uncertainty about its reality and significance. The increase in sediment accumulation rate could have occurred suddenly or over a period of time, but in any case must have taken place no earlier than the uppermost Oligocene and probably occurred in the lower Miocene. These observations taken together suggest that fan sedimentation at the location of Site 718 began rapidly in the lower Miocene.

Studies conducted on land in India and Pakistan also show that a major increase in erosion and sedimentation occurred in the lower Miocene. Johnson et al. (1985) carried out extensive paleomagnetic studies on the Potwar Plateau in Pakistan. They found that molasse sedimentation began there at about 18.3 Ma and that the initial sedimentation rates were comparable to those maintained throughout the lower and middle Miocene. The basal unit of the Siwalik molasse (the Kamlial or Murree formation) rests unconformably on Eocene marine limestones. A similar pattern is found along the entire southern edge of the Himalayas, where drilling in the Ganga Basin has consistently found continental sediments, described as equivalent to lower Siwalik or Murree, resting unconformably

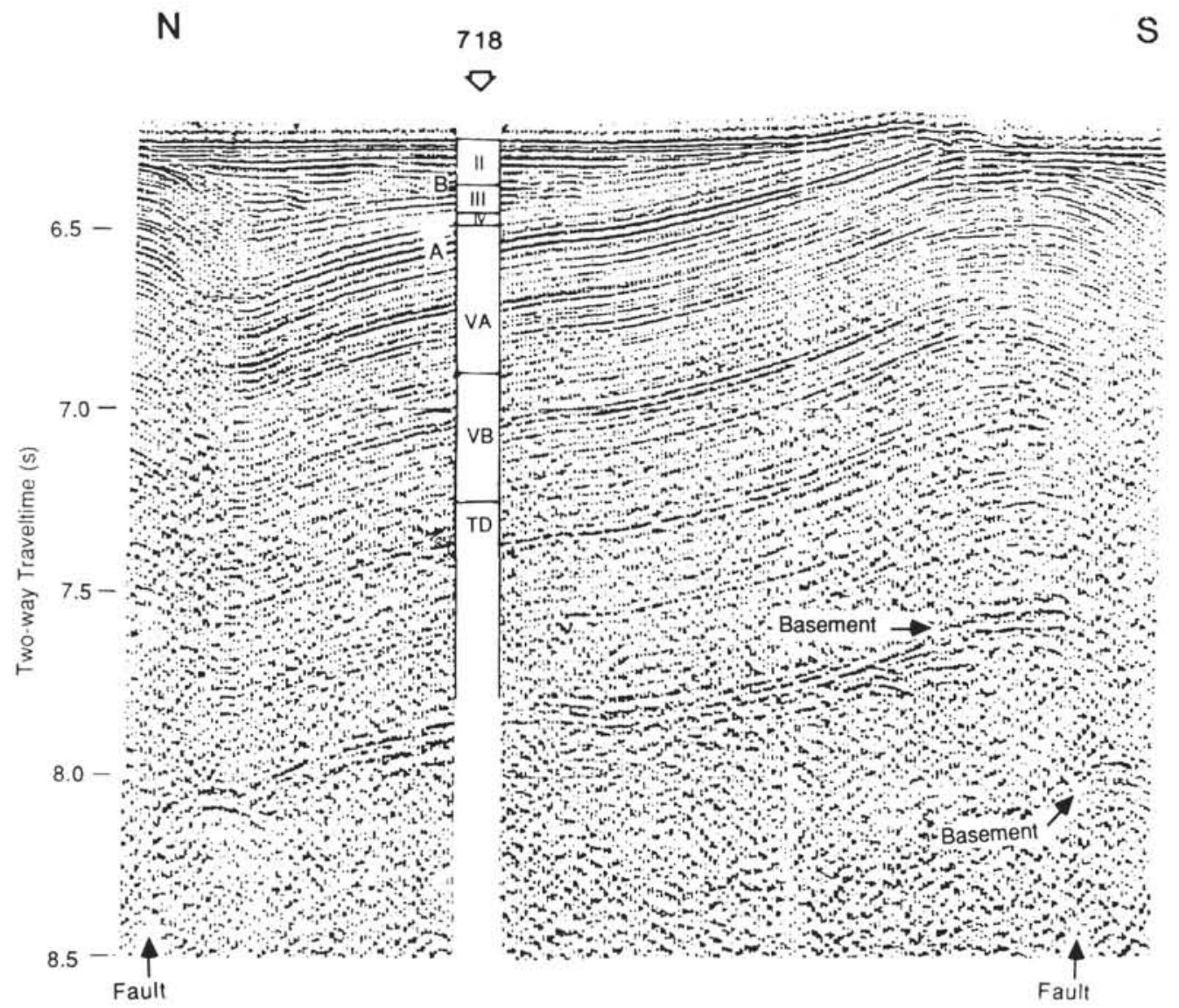

Figure 6. Single-channel seismic reflection line over Site 718. The lithologic units from Hole 718C are shown with depth converted to two-way traveltime using the sonic logs from Holes $718 \mathrm{C}$ and $718 \mathrm{E}$. Unconformities "A" and "B" are noted to the left of the lithologic column. The length of the profile is about $9.3 \mathrm{~km}$. 
on Eocene or older rocks (Rao, 1973). In addition, fission track and ${ }^{40} \mathrm{Ar} /{ }^{39} \mathrm{Ar}$ data indicate that major unroofing of plutons in the Trans-Himalayan batholith occurred in the lower Miocene (20-17 Ma) (Zeitler, 1985; Copeland et al., 1987) implying greatly increased erosion, presumably resulting from uplift, at that time.

Fan sedimentation in the northern Bay of Bengal probably began soon after the India-Eurasia collision and certainly would have begun prior to the Miocene. However, the coincidence in time between the onset of fan sedimentation at the ODP Leg 116 sites and the earliest known molasse sediments in India suggests that there was a massive increase in the delivery of sediments and very rapid progradation of the fan at that time.

The present Bengal Fan is characterized by very gentle slopes. Emmel and Curray (1984) report a gradient of 0.74 $\mathrm{m} / \mathrm{km}\left(0.042^{\circ}\right)$ for the distal fan south of $6^{\circ} \mathrm{N}$, and even as far north as about $15^{\circ} \mathrm{N}$, they calculate an average gradient of only $0.85 \mathrm{~m} / \mathrm{km}\left(0.049^{\circ}\right)$. If the large turbidites capable of traveling for thousands of kilometers across such low slopes began to be delivered to the Bay of Bengal in the lower Miocene, they would have encountered seafloor which sloped up only very slowly to the south. The seafloor at the ODP Leg 116 sites had an age of $56 \mathrm{~m} . \mathrm{y}$. at $22 \mathrm{Ma}$. Using the Parsons and Sclater (1977) relationship for seafloor depth,

$$
d(t)=6400-3200 \exp (-t / 62.8)
$$

with $\mathrm{t}=$ seafloor age in $\mathrm{m} . \mathrm{y}$. and $\mathrm{d}=$ seafloor depth in meters, the subsidence rate at that time can be calculated to be 20.9 $\mathrm{m} / \mathrm{m}$.y. The spreading rate at the time the Leg 116 sites were created was in the range of $5-6 \mathrm{~cm} / \mathrm{y}(50-60 \mathrm{~km} / \mathrm{m} . \mathrm{y}$.) (Sclater and Fisher, 1974; Schlich, 1982; Royer and Sandwell, 1989), so the bathymetric slope was $0.35-0.42 \mathrm{~m} / \mathrm{km}\left(0.020^{\circ}-0.024^{\circ}\right)$. The seafloor gradient at that time decreased to the north as a result of the increasing age of the seafloor as well as sedimentation from the Indian continental margin (Curray and Moore, 1974) and from the proto-Bengal Fan. The Miocene bathymetric gradient actually also was lower south of the Leg 116 sites as a result of the very high spreading rates from Anomaly 29 to Anomaly 23 time (Sclater and Fisher, 1974; Patriat and Segoufin, 1988; Royer and Sandwell, 1989).

As a result of the very low bathymetric gradients existing in the lower Miocene, large Bengal Fan turbidites would have caused the fan to prograde extremely rapidly across the Bay of Bengal and central Indian Ocean. The rapid progradation of the fan can be demonstrated by comparing the pre-deformation sediment thickness at the Leg 116 sites with that observed $400 \mathrm{~km}$ to the south at the location $\left(4.5^{\circ} \mathrm{S}\right)$ of a seismic survey reported by Leger and Loudon (this volume). My interpretation of the seismic line shown by Leger and Loudon (this volume) is that the reflector they label " $B$ " represents the onset of deformation. Their reflector " $B$ " is the same distance above the basement both on the top and the base of the long-wavelength basement high. Also, packets of reflectors beneath their " $\mathrm{B}$ " do not thin across individual fault blocks. The thickness of pre-deformation sediments at $4.5^{\circ} \mathrm{S}$ is slightly over $1 \mathrm{~s}$, while the pre-deformation sediment thickness at the Leg 116 sites $\left(1^{\circ} \mathrm{S}\right)$ is $1.15-1.35 \mathrm{~s}$ (Shipboard Scientific Party, 1989a). I therefore conclude that the initiation of fan sedimentation at the Leg 116 sites in the lower Miocene was the result of greatly increased erosion and delivery of sediments to the Bengal Fan resulting in extremely rapid progradation of the fan across the central Indian Ocean (as well as the initiation of important molasse sedimentation in India). The greatly increased erosion in the Himalayas can reasonably be assumed to result from major uplift at that time.

\section{Miocene Relief of the Himalayas}

Apparent fission-track ages of detrital apatites from samples from Sites 717 and 718 were studied by Corrigan and Crowley (this volume). Copeland et al. (this volume) undertook ${ }^{40} \mathrm{Ar} /{ }^{39} \mathrm{Ar}$ dating of detrital muscovite and feldspar from the same samples, which were taken from the basal section of gray silty turbidites. Both studies found that, in general, mineral ages for the samples did not significantly exceed their depositional ages throughout both holes and concluded that a significant portion of the material in the distal Bengal Fan is first cycle detritus derived from the Himalayas. The material was thus unroofed, eroded, and transported to the distal fan very rapidly. Since this rapid erosion and vigorous transport of sediment existed throughout the sedimentary history recorded at the Leg 116 sites, the implication is that significant relief has existed in the source areas throughout that history.

The sediment accumulation rate at the ODP Leg 116 sites averaged about $60-65 \mathrm{~m} / \mathrm{m}$.y. during the lower and middle Miocene and increased to $85-110 \mathrm{~m} / \mathrm{m} . \mathrm{y}$. in the upper Miocene. The increase in sediment accumulation rate in the upper Miocene might represent increased relief and erosion in the Himalayas during that time, or it might be the result of fan deposition processes. However, in either case, significant relief in the Himalayan source region must have existed throughout the middle and upper Miocene.

\section{Upper Miocene Unconformity.}

The onset of intraplate deformation at the Leg 116 sites is marked by a well developed seismic unconformity (unconformity "A", Fig. 2), which separates a constant thickness pre-deformation sequence from a syn-deformation sequence that thins toward the top of the faulted blocks. A similar unconformity is found throughout the region of intraplate deformation on the lower Bengal Fan. Moore et al. (1974) suggested an upper Miocene age for this unconformity by tracing seismic reflectors from a region where it is well developed to DSDP Site 218.

The upper Miocene was also the time of a distinct change in the character of the sediments. The micaceous silt-mud turbidites that characterized most of the Miocene gave way to much finer grained muddy organic-rich turbidites. The difference in the sediments is well illustrated by the dramatic change in the maximum grain size between lithologic Units IV and V (Figs. 5, 7). A Messinian age in the range of 5.8-6.7 Ma is obtained for the lithologic boundary by interpolating between biostratigraphic ages at the three Leg 116 sites.

Wireline logs were obtained in Holes $718 \mathrm{C}, 718 \mathrm{E}$, and 719B. Synthetic seismograms were calculated for Sites 718 and 719 using acoustic impedance values obtained from the wireline $\log$ bulk density and compressional wave velocity measurements. The synthetic seismogram utilized a 1-D convolution of a digitized Robert D. Conrad water-gun signature with the log-derived acoustic impedance. The program includes the effects of internal multiples, but not seafloor multiples. The acoustic impedance profile and synthetic seismogram are shown along with the lithologic column for Site 718 in Figure 8 and for Site 719 in Figure 10, and the synthetic seismogram is compared with observed seismic records over the two sites obtained by Robert D. Conrad in Figures 9 and 11. The top of lithologic Unit $\mathrm{V}$ is marked by a sudden increase in acoustic impedance in both holes. The resulting reflector, labeled " $\mathrm{Z}$," does not correspond to the unconformity " $A$ " at either site (Figs. 9, 11).

Unconformity " A" is located $0.09 \mathrm{~s}$ or $86 \mathrm{~m}$ below the top of lithologic Unit V at Site 718, at a depth of about 275 mbsf. Interpolation between biostratigraphic datums gives an age of 


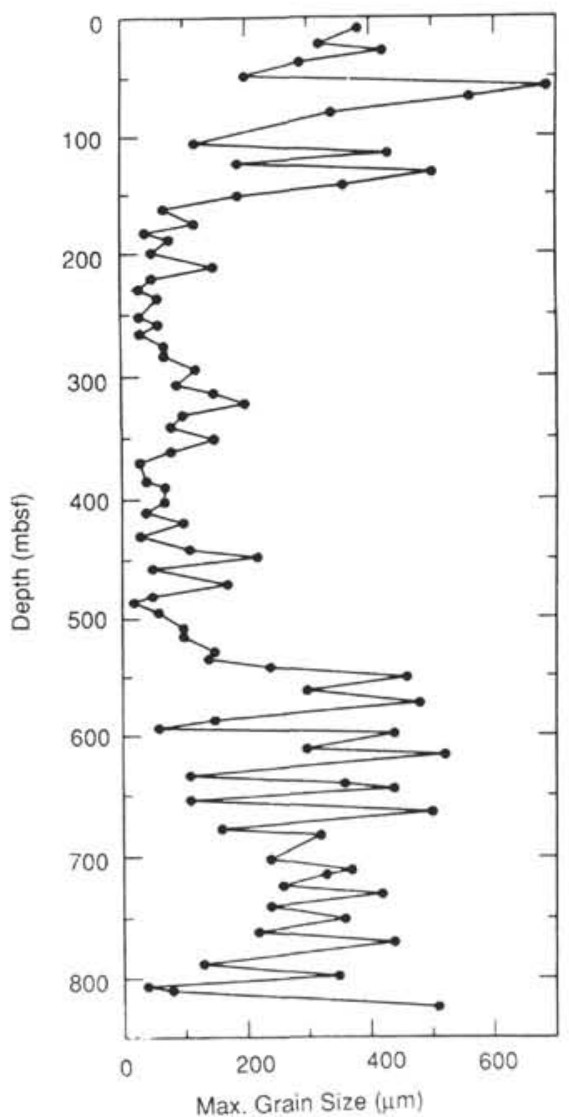

Figure 7. Plot of maximum grain size against depth for ODP Site 717.

7.6 Ma for unconformity "A" at Site 718. At Site 719 the unconformity is found at $0.092 \mathrm{~s}$, equivalent to $93 \mathrm{~m}$, below the top of Unit V. This places it near the bottom of the hole at a depth of 450 mbsf. It is below the deepest biostratigraphic datum (5.9 Ma) at Site 719. I do not believe that the sediment accumulation curve for Site 719 can be extrapolated to estimate an age for unconformity " $\mathrm{A}$ " with any more precision than to say that it is in the range of 7-8 Ma. If the reflectors corresponding to unconformity " $\mathrm{A}$ " and the top of Lithologic Unit V (reflector Z) are traced from Site 719 to Site 717, they are found to be separated by about $0.095 \mathrm{~s}$ (Fig. 12). As logging was unsuccessful at Site 717 , we do not have measured seismic velocities with depth. However, this time interval probably corresponds to about $100 \mathrm{~m}$ (assuming $\mathrm{V} p=2.1$ $\mathrm{km} / \mathrm{s}$ at that depth) which means that unconformity " $\mathrm{A}$ " is at a depth of about $635 \mathrm{~m}$. Interpolation between biostratigraphic dates gives an age of $7.75 \mathrm{Ma}$ for this depth, in substantial agreement with the result obtained at Site 718 . The beginning of intraplate deformation at the Leg 116 sites thus appears to have occurred at 7.5-8.0 Ma. It is not synchronous with the major upper Miocene change in the character of the sediments which occurred 1-2 m.y. later.

The sudden change from gray silty turbidites to black muddy turbidites in the uppermost Miocene was accompanied by a decrease in the sediment accumulation rate from about $100 \mathrm{~m} / \mathrm{m} . \mathrm{y}$. in the upper Miocene to about $70 \mathrm{~m} / \mathrm{m} . \mathrm{y}$. during the Pliocene at Site 717, where the record is most complete. Provenance studies have shown that the change in the nature of the sediments corresponds to a major change in the supply of sediment to the Bengal Fan. As discussed above, the clay mineralogy of the coarser gray silty turbidites characteristic of

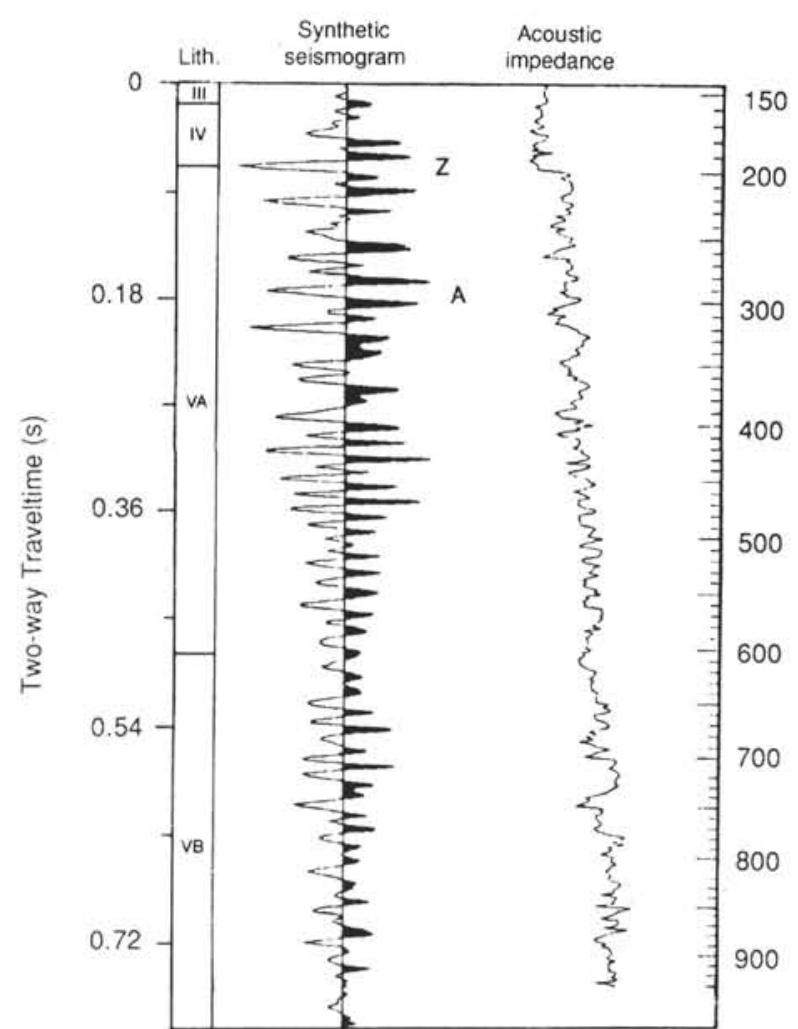

Figure 8. Synthetic seismogram for Site 718. Seismogram was calculated by convolution of the digitized Robert $D$. Conrad air-gun signature with the acoustic impedance profile shown. Acoustic impedance was determined from sonic velocity logs assuming a constant bulk density. Lithologic column for Site 718 is shown at left. The two-way traveltime scale is linear and is measured from the top of the logged interval (140 mbsf). " $\mathrm{Z}$ " is "the" reflector resulting from the uppermost Miocene change in lithology. " $\mathrm{A}$ " is unconformity " $\mathrm{A}$ " associated with the onset of intraplate deformation (See Fig. 9).

stratigraphic Units II and V is very different from that of the fine black muddy turbidites characteristic of stratigraphic Units III and IV. The clay mineralogy studies (Bouquillon et al., this volume; Brass and Raman, this volume) determined that the clay sized fraction of the silty turbidites is primarily illite and chlorite, while the muddy turbidites contain significant quantities of smectite and kaolinite. Both groups concluded that illite and chlorite represent a signature of sediment originally derived from the Himalayas, while the combination of smectite and kaolinite suggests a source in peninsular India. However, the fission track (Corrigan and Crowley, this volume) and ${ }^{40} \mathrm{Ar} /{ }^{39} \mathrm{Ar}$ (Copeland et al., this volume) studies continue to show very rapid erosion and transport of sediments during the Pliocene. The samples for these two studies were taken from the basal units of the silty gray (Himalayan) turbidites interspersed in lithostratigraphic Units III and IV (Corrigan and Crowley, this volume). Thus, large relief and rapid erosion appears to have continued in the Himalayas during the Pliocene, but changes occurred in the sediment transport regime so that less of this material and more material from peninsular India reached the distal fan.

The most likely cause for the change in sediment type during the Messinian appears to be a rise in mean sea level. The Leg 116 lithostratigraphic column is compared with a recent eustatic sea level curve (Haq et al., 1987) in Figure 13. Sea level was generally falling or nearly constant during the deposition of Unit V, according to this curve. The change in 


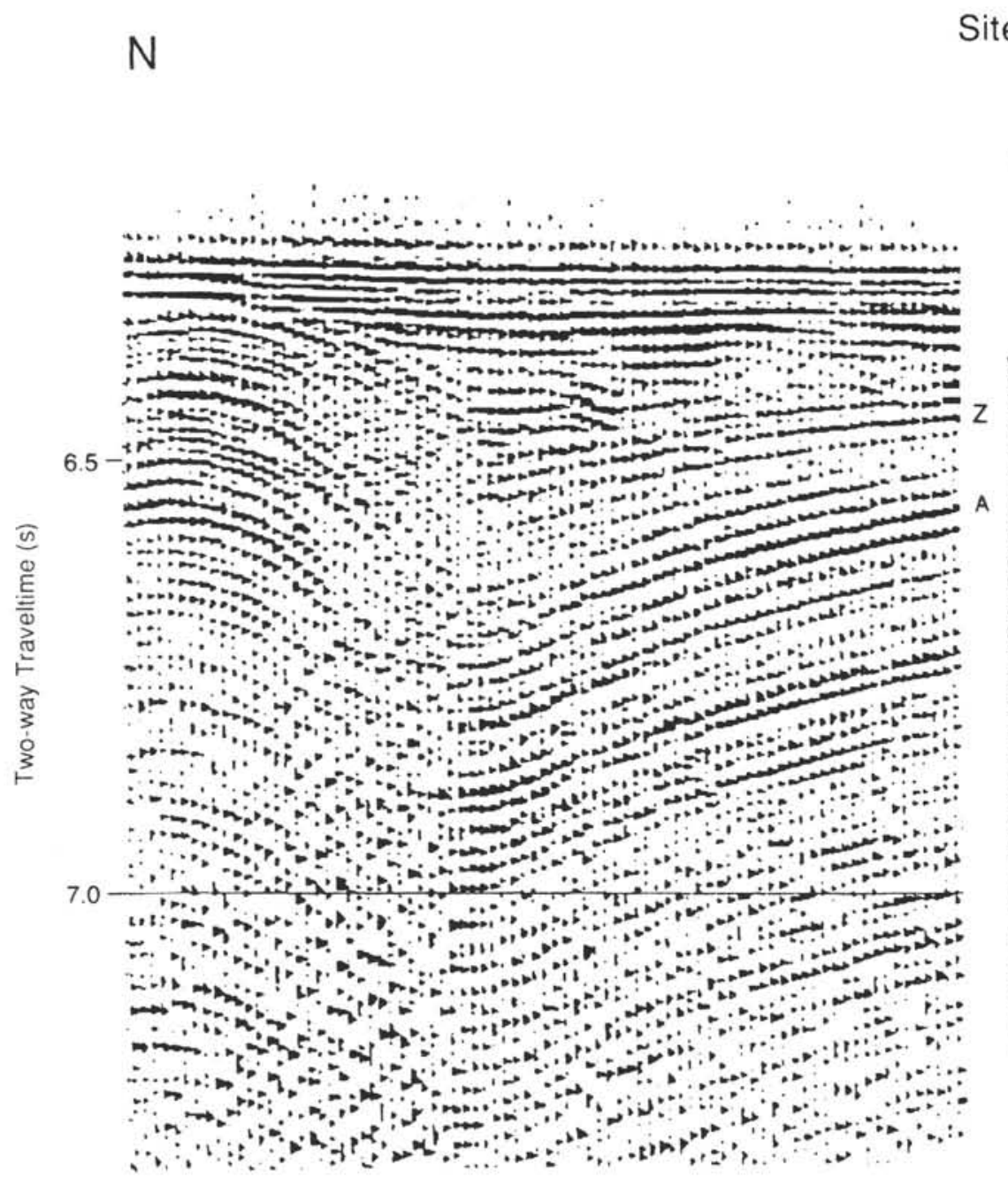

Figure 9. Single-channel seismic reflection record across Site 718 obtained by Robert D. Conrad compared with synthetic seismogram constructed from sonic log data from Site 718 (Fig. 8). Reflector " $\mathrm{Z}$ " and unconformity " A" are noted.

sediment type between stratigraphic Units V and IV corresponds in time with a rapid major increase in sea level. The generally falling sea level throughout the Miocene would cause the sediment load of the Ganges-Brahmaputra River system to be deposited on the outer portion of the shelf or to be delivered directly to the shelf edge or to canyons cutting the shelf. With the rise in sea level in the Messinian, the depocenter would have shifted landward causing much of the sediment load of the two rivers to be cut off from the fan.

The cause for the beginning of intraplate deformation in the upper Miocene is not clear. Cloetingh and Wortel $(1985,1986)$ have emphasized the importance of plate boundary geometry and forces applied at the plate boundaries in explaining the state of stress within the Indian Plate. In particular, they find that the focusing of large compressive stresses in the eastern central Indian Ocean results from compressive resistance associated with the Himalayan collision, combined with variations in the age of the lithosphere being subducted along the Sunda Trench. It is possible that the onset of intraplate deformation resulted from a change in these parameters.

Armijo et al. (1986) document a change in the tectonic regime in southern Tibet on the Eurasian side of the Himalayan collision zone which they date as occurring at $2 \pm 0.5$ Ma.. At that time, there was a change from north-south compressional deformation to west-northwest-east-southeast extension in southern Tibet, resulting in the formation of large rifts trending perpendicular to the convergence zone. Mercier et al. (1987) note this same change from a compressional to an extensional regime in southern Tibet, but state that it appears to have taken place in the upper Miocene (5-10 Ma). Armijo et al. (1986) relate the change in tectonics to the increased elevation of the Tibetan plateau and the resulting increase in the value of vertical principal stress due to the weight of the elevated mass. They suggest that, by the Pliocene, uplift had progressed to the point that the horizontal principal stress perpendicular to the convergence direction became the least compressive stress, allowing west-northwest-east-southeast extension. Armijo et al. (1986) also argue that the east-west extension in southern Tibet was laterally constrained by the Himalayan syntaxes resulting in the differing tectonic styles in northern and southern Tibet. Mercier et al. (1987) conclude that this implies that the change in the stress pattern made it more difficult for the northward motion of India to be accommodated by north-south shortening (through east-west extension) in southern Tibet. Increased resistance across this plate boundary could be speculated to have resulted in the observed focussing of large compressive stresses in the eastern Central Indian Ocean, triggering the onset of intraplate deformation. If this speculation is valid, then an upper Miocene age is implied for the beginning of extension in southern Tibet. 


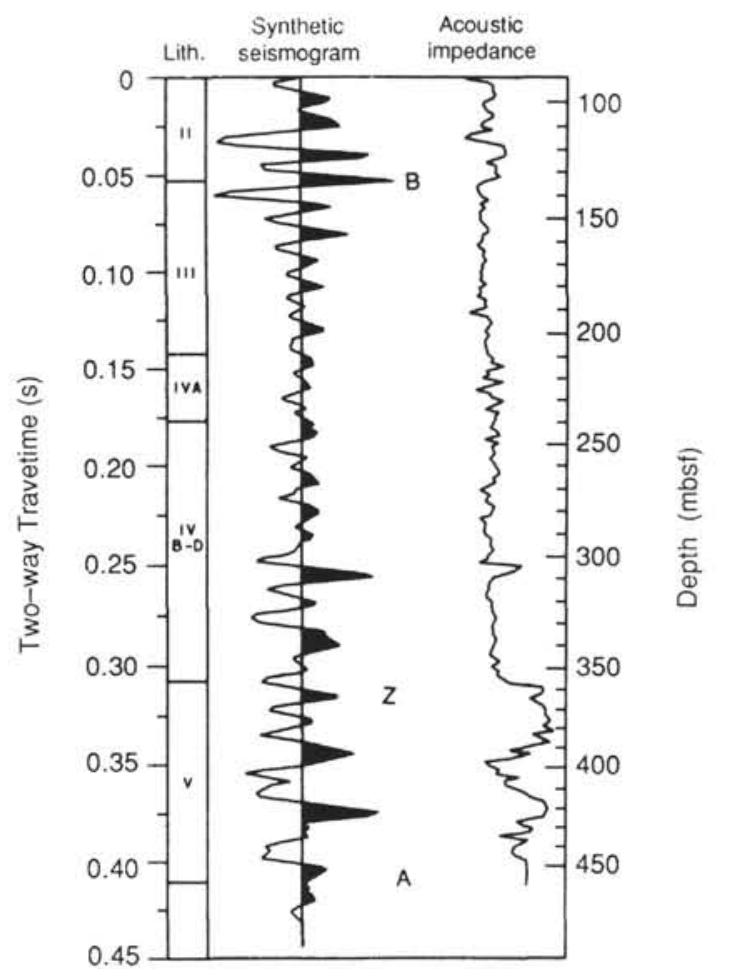

Figure 10. Synthetic seismogram for Site 719. Seismogram was calculated by convolution of the digitized Robert D. Conrad air-gun signature with the acoustic impedance profile shown. Acoustic impedance was determined from sonic velocity and bulk density logs. Lithologic column for Site 719 is shown at left. The two-way traveltime scale is linear and is measured from the top of the logged interval ( $90 \mathrm{mbsf}$ ). " $\mathrm{Z}$ " is the reflector resulting from the uppermost Miocene change in lithology. "A" and " $\mathrm{B}$ " are unconformities " $\mathrm{A}$ " and " $\mathrm{B}$ " (See Fig. 11).

\section{The Pleistocene Unconformity}

The uppermost major event recorded in the sediment record at the Leg 116 sites is the return, in the upper Pleistocene, to the deposition of coarse silty turbidites, which form lithostratigraphic Unit II (Fig. 3). These sediments are similar to those found in the coarser portions of lithostratigraphic Unit V, but were deposited at much higher rates. Sediment accumulation rates of $250-284 \mathrm{~m} / \mathrm{my}$ were calculated for intervals during the last million years at Sites 717 and 719 (Fig. 4) (Cochran, Stow, et al., 1989).

The synthetic seismogram constructed from wireline log data at Site 719 confirms that the base of Unit II corresponds to unconformity "B" (Figs. 10, 11). Interpolation between biostratigraphic horizons gives an age for unconformity "B" of $0.77 \mathrm{Ma}$ at Site 717, 0.82 Ma at Site 718, and $0.86 \mathrm{Ma}$ at Site 719. These dates should probably be considered as maximum ages, as the interpolations all utilize a $0.93 \mathrm{Ma}$ datum (the small Gephyrocapsa apex) found within the more slowly deposited Unit III sediments (Cochran, Stow, et al., 1989).

A period of low sediment accumulation lasting from the upper Pliocene to the middle Pleistocene was observed at all three sites (Fig. 4). This could in part be due to erosion, particularly for Site 719, which is in the region where reflectors in the underlying sediments are truncated by Unconformity "B" (Figs 2, 11). However, there also appears to be a hiatus or condensed section contained entirely within the Unit III sediments slightly below the unconformity (Cochran, Stow, et al., 1989). This is particularly clear at Site 717, which has the most complete post-Miocene section. The condensed section spans slightly less than 1 m.y. at Site 717 . The most likely explanation is that the main depocenter shifted to another part of the fan during that time. No other such interval has been identified at the Leg 116 sites. However, biostratigraphic dating of the Miocene section is of limited resolution and it is not likely that a $1 \mathrm{~m} . \mathrm{y}$. condensed section could be detected.

Prior to interpreting the upper Pleistocene change in sediment type and accumulation rate responsible for the formation of unconformity " $\mathrm{B}$ " in terms of events affecting either the northern Bay of Bengal, or the Himalayan source area, it is necessary to establish that it actually is a regional, fan-wide event. This requirement arises from the fact that the most recently active fan channel has been traced to only $100 \mathrm{~km}$ north of the Leg 116 sites (Emmel and Curray, 1984). It is thus possible that the change in sedimentation reflects the establishment of this channel and is not related to events in the source regions.

The simplest method to demonstrate that the upper Pleistocene event is of regional significance is to trace unconformity " $\mathrm{B}$ " throughout a large portion of the fan. This exercise is complicated by the fact that the intraplate deformation suffered by the central Indian Ocean has elevated areas up to $50-100 \mathrm{~km}$ wide above the level of the distal fan, so that they are not receiving sediments (Weissel et al., 1980; Geller et al., 1983). The reflector representing the unconformity is truncated against these uplifted sediments. However, in general, a similar unconformity is observed at the same depth in the fan sediments on the other side of the uplifted region. We assume this to be the same event. A second difficulty results from the fact that most of the seismic records available to us are older "burned paper" analog records that were not digitally recorded and thus cannot be reprocessed. The upper portion of the sediments on these records is often obscured by a significant bubble pulse from the air guns. Also, in several cases, the gain on the analog records was set so high in an attempt to image the basement that the upper portion of the sediments is burned out. This serves to limit the number of seismic lines that can be used to trace the unconformity, which is located only about $200 \mathrm{~ms}$ below the seafloor.

However, even given these limitations, unconformity "B" can be traced on a network of intersecting seismic lines through a large portion of the distal fan between the Ninetyeast Ridge and the Indrani fracture zone (Fig. 1). Figures 14 and 15 show its appearance at two widely separated places on the distal fan, near the Ninetyeast Ridge $800 \mathrm{~km}$ southeast of the Leg 116 sites at $4.5^{\circ} \mathrm{S}, 87.5^{\circ} \mathrm{E}$ (Fig. 14), and $365 \mathrm{~km}$ to the north-northeast of the Leg 116 sites at $1^{\circ} \mathrm{N}, 84^{\circ} \mathrm{E}$ (Fig. 15).

Unconformity " $\mathrm{B}$ " becomes difficult to trace north of about $6^{\circ} \mathrm{N}$. This is because the intraplate deformation is much more subdued in that region and, as a result, the unconformity loses its basic character, which is a surface separating basically flat-lying reflectors from underlying tilted or undulating reflectors (Figs. 14, 15). The upper Pleistocene event may, however, correspond to the Pleistocene pulse of coarse turbidites reported at Site 218 at $8^{\circ} \mathrm{N}$. We were also unable to trace the unconformity west of the Indrani fracture zone near $79^{\circ} \mathrm{E}$.

An additional reason for concluding that the upper Pleistocene increase in the sediment accumulation rate is a regional event is that the age of unconformity " $\mathrm{B}$ " is $800 \mathrm{k.y}$., which is considerably longer than the lifetime of any single channel. In addition to the presently active channel that terminates near the Leg 116 sites, Emmel and Curray (1981) report at least seven abandoned channels on the mid-fan region in sediments they describe as "Wisconsin" $(<100$ k.y. $)$ in age. Numerous channels can be observed on seismic reflection 

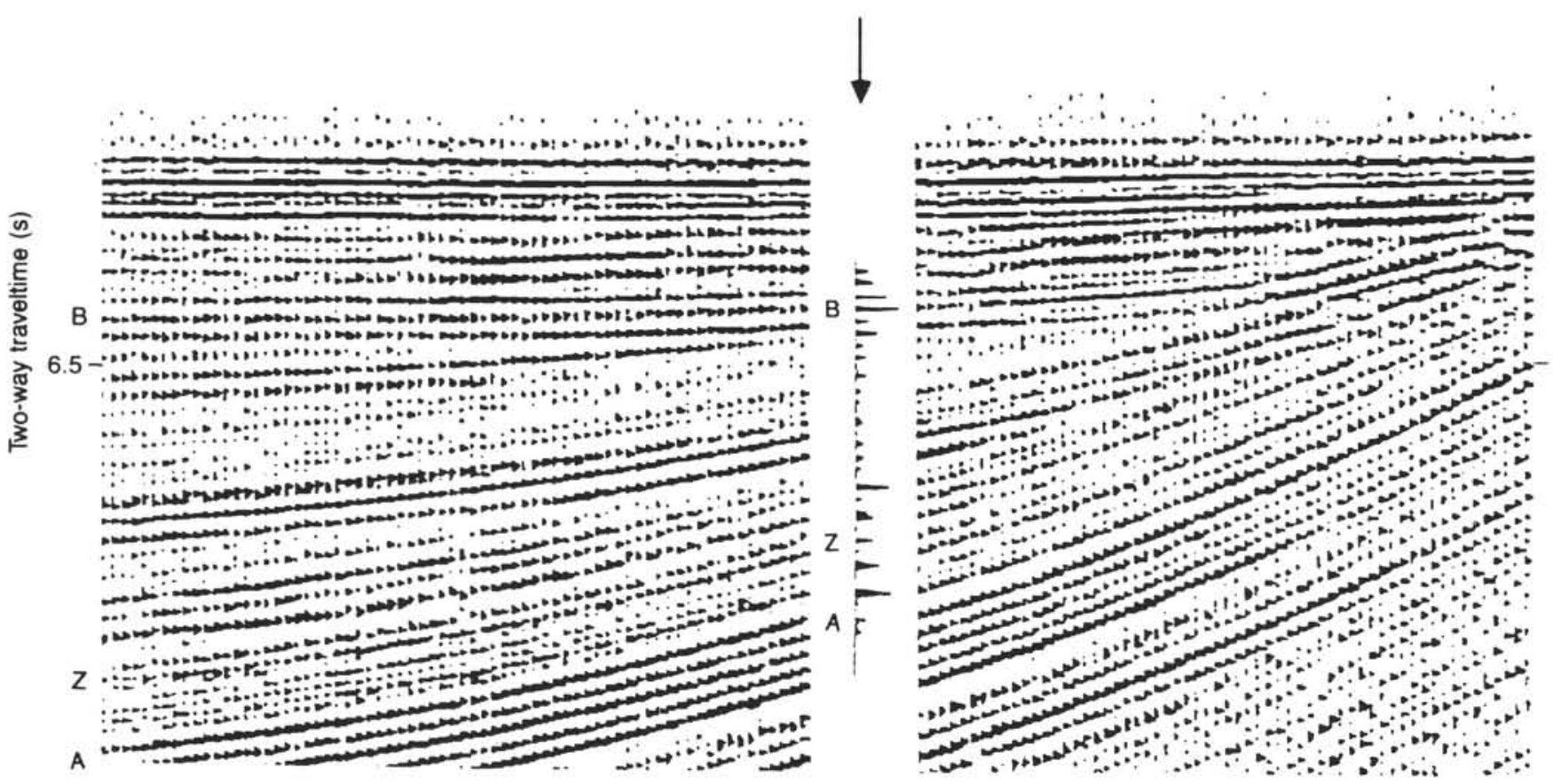

Figure 11. Single-channel seismic reflection record across Site 719 obtained by Robert D. Conrad compared with synthetic seismogram constructed from sonic and bulk density log data from Site 719 (Fig. 10). Reflector "Z" and unconformities "A" and "B" are noted.

records from all parts of the distal fan, either at the surface or buried between the surface and unconformity " $B$ ".

Seismic records indicate that uplift of the upper edge of the rotated fault blocks roughly kept pace with sedimentation from the upper Miocene to the middle Pleistocene at the Leg 116 drill sites. This resulted in the deposition of a section in which reflectors between unconformities " $\mathrm{B}$ " and " $\mathrm{A}$ " become increasingly more tilted with depth (Figs. 2,11). Small offsets of the sea bottom and faults observable on $3.5 \mathrm{Khz}$ PDR records around the Leg 116 sites, as well as abundant seismicity throughout the central Indian Ocean (Stein and Okal, 1978; Weissel et al., 1980; Bergman and Solomon, 1985), indicate that the deformation continues to the present. The coarse turbidites above unconformity " $\mathrm{B}$ " are flat lying and lap onto and over the top of the rotated fault blocks. They appear to represent a major pulse of sedimentation which completely overwhelmed the uplift due to motion on the faults.

Increased erosion resulting from a pulse of uplift in the source regions would appear to be a simple explanation for the upper Pleistocene pulse of coarse turbidites. Gansser (1964, 1966, 1981a, 1981b) has long argued for two distinct periods of orogenic activity in the Himalayas, in the lower Miocene and in the Pleistocene, separated by a period of relative quiescence. Rapid sedimentation and tilting of Pliocene deposits in intermontane basins on the northern flanks of the Himalayas (Fort et al., 1981, 1982; Burbank and Johnson, 1983) have been used to argue for recent uplift of the High Himalayas.

A number of paleoclimatic studies based primarily on pollen studies have also concluded that significant PliocenePleistocene uplift of the Tibetan Plateau has occurred. In particular, upper Miocene pollen indicative of a warm, moist subtropical forest environment at elevations of less than 1.5-2 $\mathrm{km}$ are now found at an elevation of over $4 \mathrm{~km}$ (Hsü, 1978).
Mercier et al. (1987) compiled data from 12 paleobotanical studies, mostly by Chinese investigators, and concluded that Tibet had probably reached half of its present mean altitude of $4500 \mathrm{~m}$ by the end of the Miocene and was at a mean elevation of about $3000 \mathrm{~m}$ at the end of the Pliocene. Thus, although significant rapid uplift of the Tibetan Plateau has probably occurred since the end of the Pliocene, this is a continuation of a process which began earlier in the Miocene and is unlikely in itself to produce the sudden influx of coarse turbidites in the upper Pleistocene.

A more likely cause for the sudden upper Pleistocene change in sedimentation is sea level variations resulting from Pleistocene glaciation. Significant northern hemisphere glaciation began at about $2.4 \mathrm{Ma}$, in the Pliocene (Shackleton et al., 1984; Prell, 1984; Ruddiman et al., 1986). This event is much earlier than the upper Pleistocene change in fan sedimentation and is not reflected in the sediment record at the Leg 116 sites. However, isotopic (primarily $\delta^{18} \mathrm{O}$ ) and $\% \mathrm{CaCO}_{3}$ data show that a major change in the pattern of climatic variations occurred at about 800 ka (Prell, 1982; Ruddiman et al., 1986; Ruddiman and Raymo, 1988). During the upper Pliocene and lower Pleistocene (approximately 2.4-0.8 Ma), the climatic indicators showed moderate amplitude variations predominantly at the 41-ka orbital obliquity period (Ruddiman et al., 1986). During the middle Pleistocene, a sudden change occurred to larger amplitude climatic variations dominated by the longer $100 \mathrm{ka}$ orbital eccentricity period. The first prominent $\delta^{18} \mathrm{O}$ maximum, implying greatly increased ice volume, occurred in isotopic stage 22 at $0.85-0.80 \mathrm{Ma}$ (Shackleton and Opdyke, 1973). This date is in good agreement with the beginning of the deposition of coarse lithostratigraphic Unit II turbidites at the ODP Leg 116 sites (Cochran, Stow, et al., 1989). 


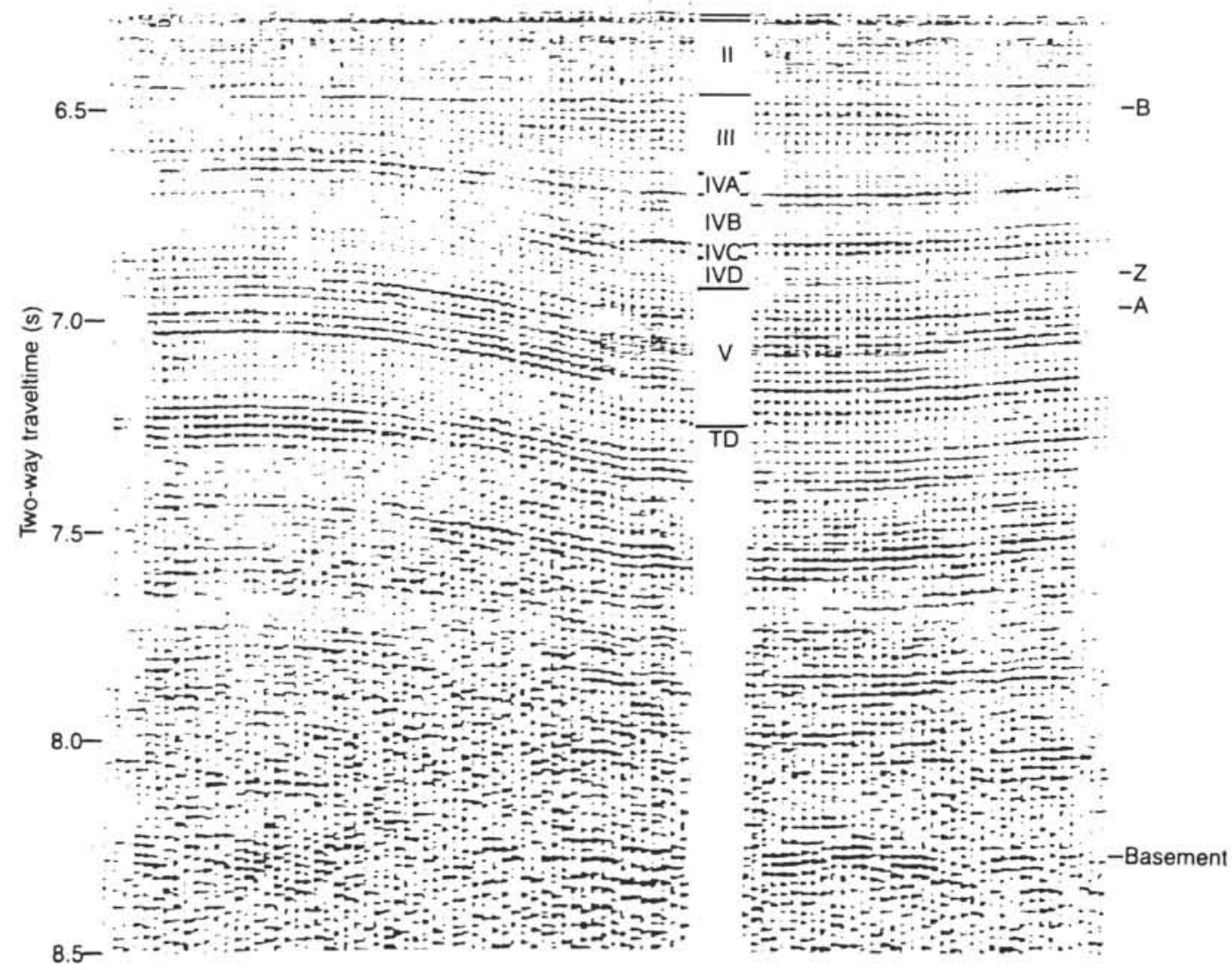

Figure 12. Single-channel seismic reflection record across Site 717 obtained by JOIDES Resolution. Lithologic units from Hole $717 \mathrm{C}$ are shown at the location of Site 717 with depths to lithologic boundaries converted to two-way traveltime. The position of the lithologic boundaries in the seismic section were determined by tracing reflectors from Site 719 where a synthetic seismogram constrained by well-log data allowed a tie between the cores and the seismic section (Fig. 11). Reflector " $\mathrm{Z}$ " and unconformities "A" and "B" are labeled to the right of the seismic section. The total length of the profile shown is about $5 \mathrm{~km}$.

The longer and more intense upper Pleistocene glacial cycles are unlikely to have resulted in greater erosion in the Himalayas, as a number of studies indicate that the summer monsoon is weaker during periods of widespread glaciation (Cullen, 1981; Duplessy, 1982; Prell and Van Campo, 1986) resulting in less rainfall north of $10^{\circ} \mathrm{N}$ on the Indian mainland. However, the greater quantity of water tied up in continental ice sheets during the upper Pleistocene implies greater amplitude sea-level variations after the change in climatic response at $800 \mathrm{ka}$. At that time, variations in $\delta^{18} \mathrm{O}$, which is considered to be a measure of ice volume, increased by $50 \%-100 \%$ (Prell, 1982; Ruddiman et al., 1986). An increase in the amplitude of the glacial-interglacial sea-level variations resulting in the exposure of the outer shelf or the shelf edge can provide the type of "threshold" phenomenon necessary to explain the sudden change in Bengal Fan sedimentation at 800 ka.

Prell (1982) used a linear relationship between variations is $\delta^{18} \mathrm{O}$ and sea-level changes (Fairbanks and Matthews, 1978) to estimate that the envelope of sea-level variations was approximately $180 \mathrm{~m}$ in the upper Quaternary and $100 \mathrm{~m}$ in the lower Quaternary and pointed out that this should result in a different pattern of transgressions and regressions during the two intervals. He concluded that, in general, "the early
Quaternary should be characterized by eustatic transgressions and regressions in the middle to inner shelf regions, whereas late Quaternary transgressions and regressions should affect the entire shelf, including shelf break in many areas" (Prell, 1982, p. 462).

Mix and Ruddiman (1984) argue that the relationship between $\delta^{18} \mathrm{O}$ and ice volume is probably non-linear. They state that, in the worst case, a linear relationship could misrepresent the amplitude of ice volume change by as much as $30 \%$. However, the difference between the two modes is quite significant and Prell's (1982) comments on its probable effects on the pattern of transgressions and regressions appear to remain valid.

\section{SUMMARY AND CONCLUSIONS}

1. Three sites were drilled on the distal Bengal Fan near $1^{\circ} \mathrm{S}, 81^{\circ} 24^{\prime} \mathrm{E}$ during ODP Leg 116 . Sites 717 and 718 penetrated 1300 of the $2000 \mathrm{~m}$ of section present at that location. The sediments recovered consist almost entirely of turbidites of terrigenous origin, derived primarily from the northern Bay of Bengal. The dominant facies from the base of Hole 718E in the lower Miocene (about $17 \mathrm{Ma}$ ) until the uppermost Miocene is gray, micaceous, silty mud turbidites. 


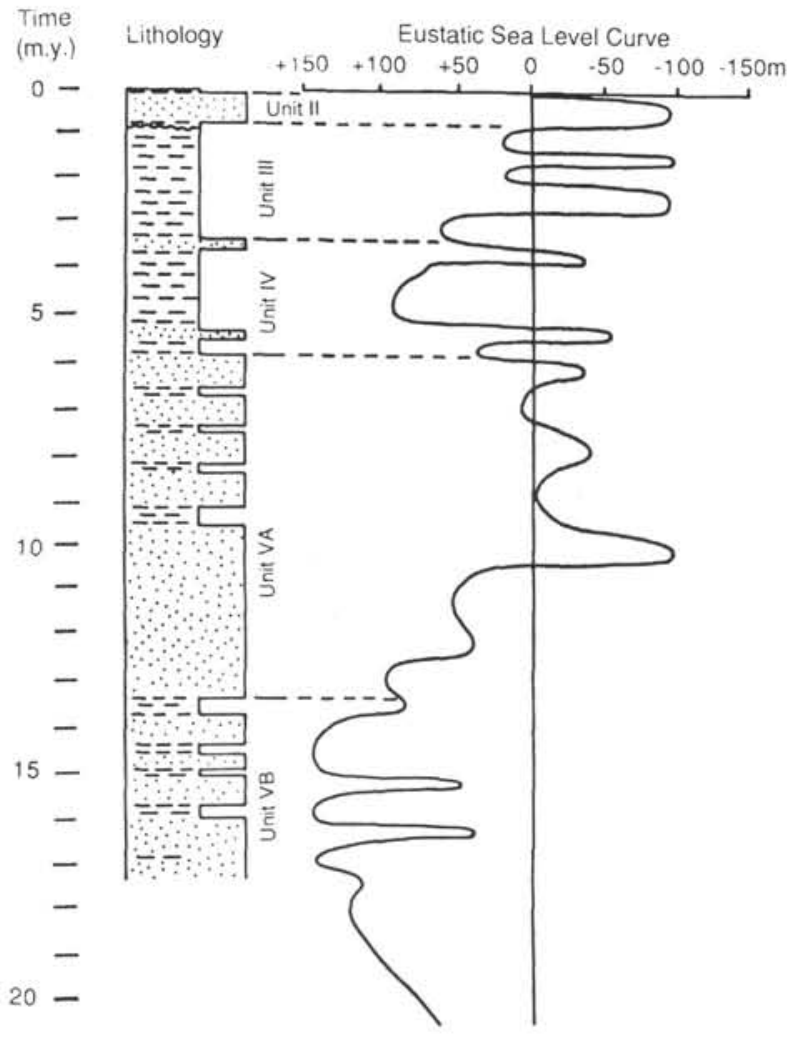

Figure 13. Eustatic sea-level curve from Haq et al. (1987) compared with composite lithostratigraphic column from Leg 116 sites.

Near $4.5^{\circ} \mathrm{S}, 87.5^{\circ} \mathrm{E}$

SE

NW

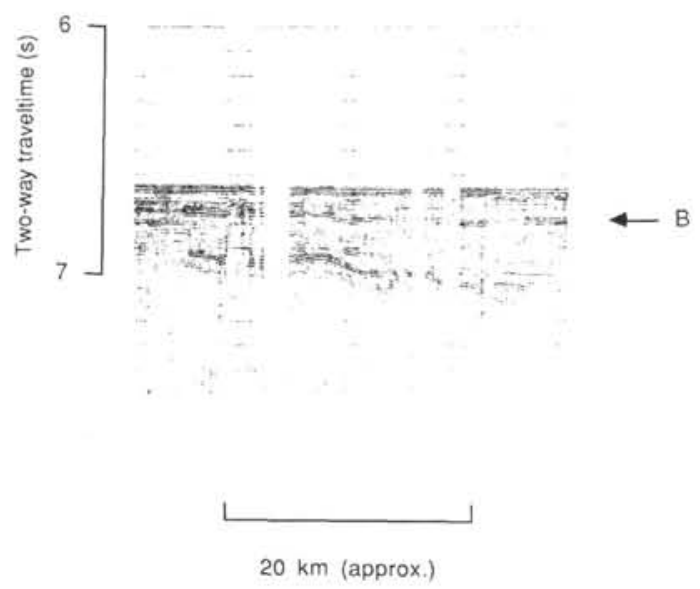

Figure 14. Single-channei seismic reflection line collected by Vema near $4.5^{\circ} \mathrm{S}, 87.5^{\circ} \mathrm{E}$ just west of the Ninetyeast Ridge. Unconformity correlated with upper Pleistocene unconformity " B" of the ODP Leg 116 sites is indicated.

These gave way in the Messinian to finer grained, black, organic-rich turbidites, which predominated until the upper Pleistocene. At that time there was a return to coarser gray silt and silty mud turbidites, which accumulated until the Holocene at much higher rates than in previous time. The primary controls on sedimentation appear to be uplift and

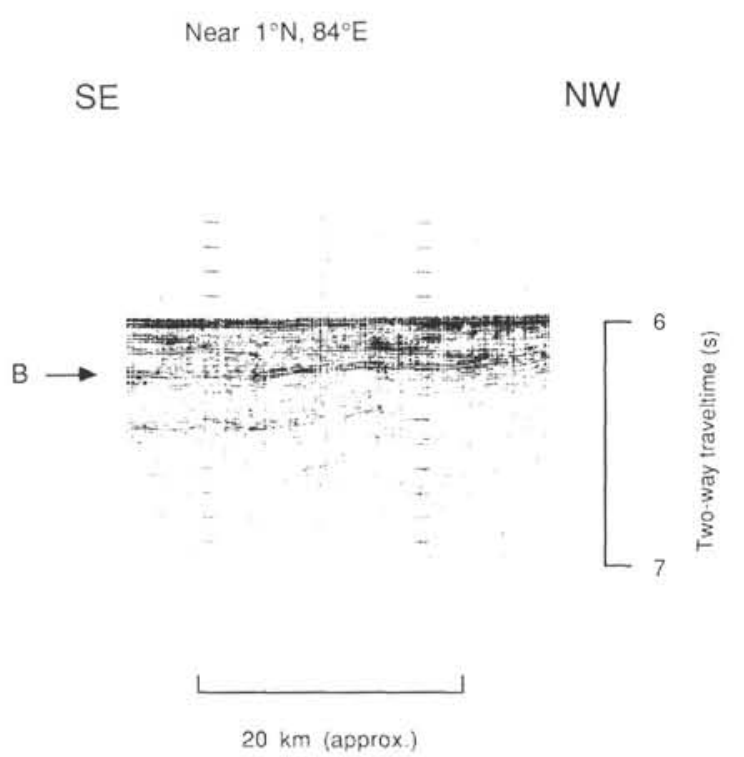

Figure 15. Single-channel seismic reflection line collected by Vema near $1^{\circ} \mathrm{N}, 84^{\circ} \mathrm{E}$. Unconformity correlated with upper Pleistocene unconformity " $\mathrm{B}$ " of the ODP Leg 116 sites is indicated.

erosion of the source areas in the Himalayas, and variations in mean sea level relative to the shelf edge. Within the somewhat coarse resolution of the biostratigraphic control, fan growth processes such as lobe and channel switching do not appear to have had a major influence on the sedimentary record at the Leg 116 sites.

2. The onset of fan sedimentation at the Leg 116 sites appears to have occurred in the lower Miocene. Although the base of the fan was not penetrated at Site 718, a number of observations suggest that it was approached. These include the appearance of intervals of pelagic red and green clays that become more common toward the bottom of Hole $718 \mathrm{C}$, along with a decrease in the maximum grain size and an increase in the calcium carbonate content near the base of Hole $718 \mathrm{C}$. In addition, if the sedimentation rate that prevailed throughout the middle and lower Miocene section (Fig. 4) is extrapolated beyond the bottom of Hole 718E, an upper Oligocene basement age is predicted. However, because the age of the basement is $78 \mathrm{Ma}$ (Shipboard Scientific Party, 1989a), the sediment accumulation rate at the site must have been much lower through much of its history and have increased dramatically in the lower Miocene. A lower Miocene date for the rapid progradation of the Bengal Fan across the southern Bay of Bengal and central Indian Ocean is consistent with the observation on land that molasse sedimentation began in the Ganga Basin during the lower Miocene. These events probably mark the beginning of large-scale uplift in the Himalayas. Sedimentation rates from the lower Miocene to the upper Pliocene (Fig. 4) require continuing rapid erosion and thus continuing uplift and significant elevation throughout this period.

3. The change to finer grained, muddy, organic-rich turbidites can be dated as occurring in the Messinian at 5.8-6.7 $\mathrm{Ma}$. The change in appearance of the sediments was also accompanied by a change in their clay mineralogy indicating increased input from peninsular India. The uppermost $\mathrm{Mi}$ ocene change in the character of the sedimentation does not correspond to the seismic unconformity marking the onset of intraplate deformation. That event occurred at 7.5-8.0 Ma and does not correspond to any noticeable change in the sedimentary record. It is tentatively suggested that the intra- 
plate deformation may result from a change in the plate boundary forces related to the beginning of east-west extension in southern Tibet. The change in the character of the sediments during the Messinian appears to result from a rise in mean sea level. This would cause the depocenter for the sediment load of the Ganges-Brahmaputra River system to shift landward resulting in a significant portion of the sediments being cut off from the shelf edge.

4. The return to the deposition of coarser silt and silty mud turbidites can be dated as occurring at close to $800 \mathrm{ka}$. This event is probably related to the intensification of the PliocenePleistocene glaciation which occurred at that time. The greater volume of water tied up in continental ice sheets during the upper Pleistocene glaciations resulted in much greater variations in sea level. The much greater sedimentation rate on the distal Bengal Fan during the upper Pleistocene suggests that the continental shelf may have been completely exposed during glacial maximums with sediment load of the rivers delivered directly to the continental slope.

\section{ACKNOWLEDGMENTS}

I thank Joe Curray, Peter Molnar, Leonardo Seeber and two anonymous reviewers for constructive criticism. I also thank Bill Ruddiman for discussions introducing me to Pliocene-Pleistocene paleoclimatology. The synthetic seismograms used in this study were constructed by Colin Williams. This work was supported by a JOI/USSAC grant for postcruise studies.

\section{REFERENCES}

Achache, J., Courtillot, V., and Zhou Y. X., 1984. Paleogeographic and tectonic evolution of southern Tibet since middle Cretaceous time: New paleomagnetic data and synthesis. J. Geophys. Res., $89: 10,311-10,339$.

Armijo, R., Tapponnier, P., and Han, T. L., 1989. Late Cenozoic right-lateral strike-slip faulting in southern Tibet. J. Geophys. Res., 94:2787-2838.

Armijo, R., Tapponnier, P., Mercier, J. L., and Han, T. L., 1986. Quaternary extension in southern Tibet: field observations and tectonic implications. J. Geophys. Res., 91:13803-13872.

Bergman, E. A., and Solomon, S. C., 1985. Earthquake source mechanisms from body-waveform inversion and intraplate tectonics in the northern Indian Ocean. Phys. Earth Planet. Inter., 40:1-23.

Besse, J., Courtillot, V., Pozzi, P., Westphal, M., and Zhou, Y. X., 1984. Palaeomagnetic estimates of crustal shortening in the Himalayan thrusts and Zangbo suture. Nature, 311:621-626.

Brookfield, M. E., and Reynolds, P. H., 1981. Late Cretaceous emplacement of the Indus suture zone ophiolitic melanges and an Eocene-Oligocene magmatic arc on the northern edge of the Indian plate. Earth Planet. Sci. Lett., 55:157-161.

Bunce, E. T., and Molnar, P., 1977. Seismic reflection profiling and basement topography in the Somali Basin: possible fracture zones between Madagascar and Africa. J. Geophys. Res., 82:5305-5311.

Burbank, D. W., and Johnson, G. D., 1983. The Late Cenozoic chronologic and stratigraphic development of the Kashmir intermontane Basin, northwestern Himalaya. Palaeogeogr., Palaeoclimatol., Palaeoecol., 43:205-235.

Cloetingh, S.A.P.L., and Wortel, M.J.R., 1985. Regional stress field of the Indian Plate. Geophys. Res. Lett., 12:77-80.

1986. Stress in the Indo-Australian Plate. Tectonophysics. 132:49-67.

Cochran, J. R., 1988. Somali Basin, Chain Ridge and the origin of the Northern Somali Basin gravity and geoid low. J. Geophys. Res., 93:11985-12008.

Cochran, J. R., Stow, D.A.V., et al., 1989. Proc. ODP, Init. Repts., 116: College Station, TX (Ocean Drilling Program).

Copeland, P., Harrison, T. M., Kidd, W.S.F., Ronghua, X., and Yuquan, Z., 1987. Rapid early Miocene acceleration of uplift in the
Gangdese Belt, Xizung (southern Tibet) and its bearing on accommodation mechanisms of the India-Asia collision. Earth Planet. Sci. Lett., 86:240-252.

Cullen, J. L., 1981. Microfossil evidence for changing salinity patterns in the Bay of Bengal over the last 20,000 years. Palaeogeogr., Palaeoclimatol., Palaeoecol., 35:315-356.

Curray, J. R., and Moore, D. G., 1971. Growth of the Bengal deepsea fan and denudation of the Himalayas. Geol. Soc. Am. Bull., 82:563-572.

, 1974. Sedimentary and tectonic processes in the Bengal deep-sea fan and geosyncline. In Burk, C. A., and Drake, C. L. (Eds.), The Geology of Continental Margins: New York (SpringerVerlag), 617-627.

Curray, J. R., and Munasinghe, T., 1989. Timing of intraplate deformation, northeastern Indian Ocean. Earth Planet. Sci. Lett., 94:71-79.

Curray, J. R., Emmel, F. J., Moore, D. G., and Raitt, R. W., 1982. Structure, tectonics and geological history of the northeastern Indian Ocean. In Nairn, A.E.M., and Stehli, F. G. (Eds.), The Ocean Basins and Margins (Vol. 6): New York (Plenum), 399450.

Duplessy, J. C., 1982. Glacial to interglacial contrasts in the northern Indian Ocean. Nature, 295:494-498.

Emmel, F. J., and Curray, J. R., 1981. Dynamic events near the upper and mid-fan boundary of the Bengal fan. Geo-Mar. Lett., 1:201-205.

1984. The Bengal submarine fan, northeastern Indian Ocean. Geo-Mar. Lett., 3:119-124.

Fairbanks, R. G., and Matthews, R. K., 1978. The marine oxygen isotope record in Pleistocene coral, Barbados, West Indies. Quat. Res., 10:181-196.

Fort, M., Freytet, P., and Colchen, M., 1981. The structural and sedimentological evolution of the Takkola-Mustang graben (Nepal Himalaya) in relation to the uplift of the Himalaya Range. In Geological and Ecological Studies of the Qinghai-Zizang Plateau, 1:307-313.

1982. Structural and sedimentological evolution of the Thakkola-Mustang graben (Nepal Himalayas). Z. Geomorphol., 42:75-98.

Gansser, A., 1964. Geology of the Himalayas, New York (Wiley). 1966. The Indian Ocean and the Himalayas, a geological interpretation. Eclogae Geol. Helv., 59:831-848.

1981a. The geodynamic history of the Himalaya. In Gupta, H. K., and Delany, F. M. (Eds.), Zagros, Hindu Kush, Himalaya Geodynamic Evolution: Am. Geophys. Union Geodyn. Ser., 3:111-121.

, 1981b. The timing and significance of orogenic events in the Himalaya. In Geological and Ecological Studies of the QinghaiZizang Plateau. 1:23-30.

Geller, C. A., Weissel, J. K., and Anderson, R. N., 1983. Heat transfer and intraplate deformation in the central Indian Ocean. $J$. Geophys. Res., 88:1018-1032.

Haq, B. U., Hardenbol, J., and Vail, P. R., 1987. Chronology of fluctuating sea levels since the Triassic. Science, 235:1156-1167.

Honegger, K., Dietrich, V., Frank, W., Gansser, A., Thoni, M., and Trommsdorf, V., 1982. Magmatism and metamorphism in the Ladakh Himalayas (the Indus-Tsangpo suture zone). Earth Planet. Sci. Lett., 60:253-292.

Hsü, J., 1978. On the palaeobotanical evidence for continental drift and Himalayan uplift. The Palaeobotonist., 25:131-142.

Johnson, B. D., Powell, C. McA., and Veevers, J. J., 1976. Spreading history of the Eastern Indian Ocean and Greater India's northward flight from Antarctica and Australia. Geol. Soc. Am. Bull., 87:1560-1566.

Johnson, N. M., Stix, J., Tauxe, L., Cerveny, P. F., and Tahirkheli, R.A.K., 1985. Paleomagnetic chronology, fluvial processes and tectonic implications of the Siwalik deposits near Chinji village, Pakistan. J. Geol., 93:27-40.

Klootwijk, C. T., 1981. Greater India's northern extent and its underthrust of the Tibetan Plateau: palaeomagnetic constraints and implications. In Gupta, H. K., and Delany, F. M. (Eds.), Zagros, Hindu Kush, Himalaya Geodynamic Evolution. Am. Geophys. Union Geodyn. Ser., 3:311-323. 
Klootwijk, C. T., Conaghan, P. J., and Powell, C. McA., 1985. The Himalayan Arc: large scale continental subduction, oroclinal bending and back-arc spreading. Earth Planet. Sci. Lett., 75:167183.

Larson, R. L., Mutter, J. C., Diebold, J. B., and Carpenter, G. B., 1979. Cuvier Basin: a product of ocean crust formation by Early Cretaceous rifting off western Australia. Earth Planet Sci. Lett., 45:105-114.

Le Fort, P., 1986. Metamorphism and magmatism during the Himalayan collision,. In Coward, M. P., and Ries, A. C. (Eds.), Collision Tectonics. Geol. Soc. London Spec. Publ., 19:159-172.

Markl, R. G., 1974. Evidence for the breakup of eastern Gondwanaland by the Early Cretaceous. Nature, 251:196-200.

1978. Further evidence for the Early Cretaceous breakup of Gondwanaland off Southwestern Australia. Mar. Geol., 26:41-48.

Mattauer, M., 1986. Intracontinental subduction, crust-mantle décollement and crustal-stacking wedge in the Himalayas and other collision belts. In Coward, M. P., and Ries, A. C. (Eds.), Collision Tectonics. Geol. Soc. London Spec. Publ., 19:37-50.

McKenzie, D. P., and Sclater, J. G., 1971. The evolution of the Indian Ocean since the late Cretaceous. Geophys. J. R. Astron. Soc., 25:437-528.

Mercier, J.-L., Armijo, R., Tapponnier, P., Caron-Gailhardis, E., and Lin, H. T., 1987. Change from late Tertiary compression to Quaternary extension in Southern Tibet during the India-Asia collision. Tectonics, 6:275-304.

Mix, A. C., and Ruddiman, W. F., 1984. Oxygen-isotope analyses and Pleistocene ice volumes. Quat. Res., 21:1-20.

Molnar, P., 1986. The geologic history and structure of the Himalaya. Am. Sci., 74:144-154.

Molnar, P., and Tapponnier, P., 1975. Cenozoic tectonics of Asia: effects of a continental collision. Science, 189:419-426.

Molnar, P., Chen, W. P., and Tapponnier, P., 1981. Constraints of the amount of north-south shortening in Tibet during the Cenozoic. In Geological and Ecological Studies of the Qinghai-Zizang Plateau, 1:757-761.

Molnar, P., Pardo-Casas, F., and Stock, J., 1988. The Cenozoic and late Cretaceous evolution of the Indian Ocean Basin: uncertainties in the reconstructed positions of the Indian, African and Antarctic plates. Basin Res., 1:23-40.

Moore, D. G., Curray, J. R., Raitt, R. W., and Emmel, F. J., 1974. Stratigraphic-seismic section correlation and implications to Bengal fan history. In von der Borch, C. C., Sclater, J. G., et al., Init. Repts. DSDP, 22: Washington (U.S. Govt. Printing Office), $403-$ 412 .

Norton, I. O., and Sclater, J. G., 1979. A model for the evolution of the Indian Ocean and the break-up of Gondwanaland. J. Geophys. Res., 84:6803-6830.

Parsons, B., and Sclater, J. G., 1977. An analysis of ocean floor bathymetry and heat flow with age. J. Geophys. Res., 82:803-827.

Patriat, P., and Achache, J., 1984. India-Eurasia collision chronology has implications for crustal shortening and driving mechanism for plates. Nature, 311:615-621.

Patriat, P., and Segoufin, J., 1988. Reconstruction of the central Indian Ocean. Tectonophysics, 155:211-234.

Petterson, M. G., and Windley, B. F., 1985. Rb-Sr dating of the Kohistan arc-batholith in the Trans-Himalaya of north Pakistan and tectonic implications. Earth Planet Sci. Lett., 74:45-57.

Powell, C. McA., 1986. Continental underplating model for the rise of the Tibetan Plateau. Earth Planet. Sci. Lett., 81:79-94.

Powell, C. McA., and Conaghan, P. J., 1973. Plate tectonics and the Himalayas. Earth Planet Sci. Lett., 20:1-12.

Prell, W. L., 1982. Oxygen and carbon isotope stratigraphy for the Quaternary of Hole 502B: evidence for two modes of isotopic variability. In Prell, W. L., Gardner, J. V., et al., Init. Repts. DSDP, 68: Washington (U.S. Govt. Printing Office), 455-464.

1984. Covariance patterns of foraminiferal $\delta^{18} \mathrm{O}$ : An evaluation of Pliocene ice volume changes near 3.2 million years ago. Science, 226:692-693.

Prell, W. L., and Van Campo, E., 1986. Coherent response of Arabian Sea upwelling and pollen transport to late Quaternary monsoonal winds. Nature, 323:526-528.
Rao, M.B.R., 1973. The subsurface geology of the Indo-Gangetic Plains. J. Geol. Soc. India, 14:217-242.

Reynolds, P. H., Brookfield, M. E. and McNutt, R. H., 1983. The age and nature of Mesozoic-Tertiary magmatism across the Indus suture zone in Kashmir and Ladakh (N.W. India and Pakistan). Geol. Rundschau, 72:981-1004.

Royer, J. Y., and Sandwell, D. T., 1989. Evolution of the eastern Indian Ocean since the late Cretaceous: constraints from Geosat altimetry. J. Geophys. Res., 94:13755-13782.

Ruddiman, W. F., and Raymo, M. E., 1988. Northern hemisphere climatic regimes during the past $3 \mathrm{Ma}$ : possible tectonic connections. Philos. Trans. R. Soc. London, 318:411-430.

Ruddiman, W. F., Raymo, M. E., and McIntyre, A., 1986. Matuyama 41,000-year cycles: North Atlantic and northern hemisphere ice sheets. Earth Planet. Sci. Lett., 80:117-129.

Sahni, A., and Kumar, V., 1974. Paleogene palaeobiogeography of the Indian subcontinent. Palaeogeogr., Palaeoclimatol., Palaeoecol., 15:209-226.

Schärer, U., Xu, R. H., and Allegre, C. L., 1984. U-Pb geochronology and Gangdese (Transhimalaya) plutonism in the Lhasa-Xigase region Tibet. Earth Planet. Sci. Lett., 69:311-320.

Schlich, R., 1982. The Indian Ocean: aseismic ridges, spreading centers, and oceanic basins. In Nairn, A.E.M., and Stehli, F. G. (Eds.), The Ocean Basins and Margins (Vol. 6): New York (Plenum), 51-147.

Schlich, R., and Fondeur C., 1974. Anomalies magnétiques crétacées dans le bassin des Mascareignes (Océan Indien). C. R. Acad. Sci. Ser. 2, 278:541-544.

Sclater, J. G., and Fisher, R. L., 1974. The evolution of the east central Indian Ocean, with emphasis on the tectonic setting of the Ninetyeast Ridge. Geol. Soc. Am. Bull., 85:683-702.

Sclater, J. G., Luyendyk, B. P., and Meinke, L., 1976. Magnetic lineations in the southern part of the Central Indian Basin. Geol. Soc. Am. Bull., 87:371-378.

Scrutton, R. A., 1978. Davie fracture zone and the movement of Madagascar. Earth Planet. Sci. Lett., 39:84-88.

Searle, M. P., Windley, B. F., Coward, M. P., Cooper, D.J.W., Rex, A. J., Rex, D., Li Tingdong, Xiao Xuchang, Jan, M. O., Thakur, V. C. and Kumar, S., 1987. The closing of Tethys and the tectonics of the Himalaya. Geol. Soc. Am. Bull., 98:678-701.

Segoufin, J., and Patriat, P., 1980. Existence d'anomalies mésozoiques dans la basin de Somalie. Implications pour les relations AfriqueAntarctique-Madagascar. C. R. Acad. Sci. Ser. 2, 291:85-88.

Shackleton, N. J., and Opdyke, N. D., 1973. Oxygen isotope and palaeomagnetic stratigraphy of Equatorial Pacific core V28-238: oxygen isotope temperatures and ice volumes on a $10^{5}$ year and $10^{6}$ year scale. Quat. Res., 3:39-55.

Shackleton, N. J., Backman, J., Zimmerman, H., Kent, D. V., Hall, M. A., Roberts, D. G., Schnitker, D., Baldauf, J. G., Despraires, A., Homrighausen, R., Huddlestun, P., Keene, J. B., Kaitenback, A. J., Krumsiek, K.A.O., Morton, A. C., Murray, J. W., and Westbury-Smith, J., 1984. Oxygen isotope calibration of the onset of ice rafting in DSDP Site 552A: History of glaciation in the North Atlantic region. Nature 307:620-623.

Shipboard Scientific Party, 1974. Site 218. In von der Borch, C. C., Sclater, J. G., et al., Init. Repts. DSDP, 22: Washington (U.S. Govt. Printing Office), 325-338.

1989a. ODP Leg 116 Site Survey. In Cochran, J. R., Stow, D.A.V., et al., Proc. ODP, Init. Repts., 116: College Station, TX (Ocean Drilling Program), 197-212.

1989b. Site 717: Bengal Fan. In Cochran, J. R., Stow, D.A.V., et al., Proc. ODP, Init. Repts., 116: College Station, TX (Ocean Drilling Program), 45-90.

1989c. Site 718: Bengal Fan. In Cochran, J. R., Stow, D.A.V., et al., Proc. ODP, Init. Repts., 116: College Station, TX (Ocean Drilling Program), 91-154.

Stein, S., and Okai, E. A., 1978. Seismicity and tectonics of the Ninetyeast Ridge area: evidence for internal deformation of the Indian Plate. J. Geophys. Res., 83:2233-2245.

Stow, D.A.V., Cochran, J. R., and ODP Leg 116 Shipboard Scientific Party, 1989. The Bengal Fan: some preliminary results from ODP drilling. Geo-Mar. Lett., 9:1-10. 


\section{J. R. COCHRAN}

Tapponnier, P., and Molnar, P., 1977. Active faulting and tectonics of China. J. Geophys. Res., 82:2905-2930.

Tapponnier, P., Mercier, J. L., Proust, F., et al., 1981. The Tibetan side of the India-Eurasia collision. Nature, 294:405-410.

Taponnier, P., Peltzer, G., and Armijo, R., 1986. On the mechanics of the collision between India and Asia. In Ramsey, J. G., Coward, M. P., and Ries, A. (Eds.), Collision Tectonics. Geol. Soc. London Spec. Publ., 19:115-157.

Tapponnier, P., Peltzer, G., Le Dain, A. Y., Armijo, R., and Cobbold, P., 1982. Propagating extrusion tectonics in Asia: new insights from simple experiments with plasticene. Geology, 10:611-616.

Thompson, R. W., 1974. Mineralogy of sands from the Bengal and Nicobar Fans, Sites 218 and 211 , Eastern Indian Ocean. In von der Borch, C. C., Sclater, J. G., et al., Init. Repts. DSDP, 22: Washington (U.S. Govt. Printing Office), 711-713.

Weissel, J. K., Anderson, R. N., and Geller, C. A., 1980. Deformation of the Indo-Australian plate. Nature, 287:284-291.

Wiens, D. A., 1985. Historical seismicity near Chagos: a complex deformation zone in the equatorial Indian Ocean. Earth Planet. Sci. Lett., 76:350-360.

Zeitler, P. K., 1985. Cooling history of the NW Himalaya. Tectonics, $4: 127-151$.

Date of initial receipt: 13 April 1989

Date of acceptance: 3 January 1990

Ms 116B-144 